Gordan Ivo Lazović

Nevio Šetić
Prethodno priopćenje

Rukopis je prihvaćen za tisak:10. listopada 2019 DOI: $10.21857 / \mathrm{m} 16$ wjc6nz9

\title{
UZROCI SUKOBLJAVANJA U ISTRI TIJEKOM OBLIKOVANJA MODERNE HRVATSKE NACIJE U DUGOM 19. STOLJEĆU
}

Uslijed djelovanja triju nacionalno-integracijskih procesa u istarskih Talijana, Hrvata i Slovenaca Istra je, posebno od sredine 19. do sredine 20. stoljeća, bila prostor nacionalnih sukobljavanja i netolerancije. Premda su postojali u to doba i pokušaji međusobno skladnog i snošljivog života, dramatična zbivanja nastupila su upravo tijekom ustrajne borbe triju naroda u Istri za vlastito pravo na nacionalnu samobitnost, identitet i samoodređenje. Posebno je bilo problematično poricanje suvereniteta naroda na tom prostoru, što je impliciralo sukobe. Uz taj krucijalni unutarnji čimbenik, u induciranju sukoba triju autohtonih naroda u Istri i na Kvarnerskim otocima u 19. stoljeću važnu su ulogu imali i neki vanjski čimbenici tijesno povezani s promjenjivim dinamizmima međunarodne politike. Nacionalno ujedinjenje Italije i ostvarenje moderne talijanske države Kraljevine Italije 1861. ključni je vanjski čimbenik političke stvarnosti i odnosa u tom prostoru. Isto tako, poraz Austrije u ratu s Pruskom (1866.) i promjena težišta njezine politike, pristupanje Italije Trojnom savezu (1882.), poraz talijanske kolonijalne vojske kod Adue (1896.) s novim obratom njezine politike u odnosu na Jadran i habsburške teritorije, ključni su vanjski čimbenici koji su utjecali na politike Kraljevine Italije, Habsburške Monarhije, kao i na razvitak društvenih, političkih i nacionalnih procesa u pokrajini Istri.

U radu se raspravlja i o značaju vanjskih, strukturalnih čimbenika, kao što je europska ravnoteža snaga, odnosno ključna regionalna ravnoteža između Italije i Austrije, koji su na posredan način određivali sudbinu i Hrvata, i Slovenaca, i Talijana u dugom 19. stoljeću. Raščlambom unutarnjih i vanjskih čimbenika istarske povijesne zbilje prikazalo se cjelovitiju sliku uzroka sukobljavanja u Istri tijekom druge polovice dugog 19. stoljeća, kao i stanja s kojim se ušlo u Veliki rat 1914. godine.

Ključne riječi: hrvatska nacionalna integracija u Istri; Hrvati; Slovenci; Talijani; Kraljevina Italija; Austro-Ugarska Monarhija. 


\section{Nacionalno ujedinjenje Italije generator talijanskog iredentizma u Istri}

Uz talijanska preporodna i nacionalnointegracijska gibanja i velike su sile omogućile, svaka iz svojih sebičnih interesa, nacionalnu unifikaciju Italije (1861.), i to sukcesivnim ratovanjem protiv Austrije, čime je bio potaknut snažan talijanski iredentizam prema habsburškim zemljama u kojima su živjeli Talijani. Talijanski je iredentizam u Istri ubrzo bio sukobljen s preporodnim i nacionalnointegracijskim težnjama Hrvata i Slovenaca koji se sustavno počinje odvijati u ranim 60-im godinama 19. stoljeća.

Već u počecima talijanskog narodnog preporoda - Risorgimenta - u Apeninima je rođen talijanski iredentizam kao pokret vođen isprva malobrojnim urotničkim skupinama tzv. „karbonara“. Oni su se prvobitno zanosili vizijom ujedinjenja "od Malte do Trentina, od Boke Kotorske do Trsta“, kako je to bilo izneseno u tzv. Ausonijskom paktu karbonara iz 1818. godine. Taj program postavio je granice buduće Republike Ausonije, koju će iredentisti kasnije koristiti kao ime buduće ujedinjene Italije, na Alpama i Dinari. No kada karbonari u svojim revolucionarnim pokušajima 1820./21. i 1831. godine propadnu, barjak iredentizma preuzet će novo revolucionarno tajno društvo - Giovine Italia - na čelu s Giuseppeom Mazzinijem. On nije imao pred očima samo usku viziju za obnovom veličine drevnoga Rima, već je naciju smatrao duhovnom kvalitetom, postulirajući i univerzalnu oslobodilačku misiju za talijanski narod. Naime, Mazzini je u borbi talijanskog naroda za ujedinjenje gledao dio šire borbe čovječanstva za emancipaciju. U tom sklopu talijanski narod imao bi povijesnu misiju da potpomaže oslobađanje svih potlačenih naroda, pa onda i Slavena, kako bi se stvorila Europa slobodnih naroda i čovječanstvo ujedinilo u bratstvu. Mazzini se tako dosljedno zalagao za oslobođenje i ujedinjenje južnih Slavena smatrajući da bi Italija morala pomagati njihovu borbu protiv Austrije i Otomanskog Carstva ${ }^{1}$. Tu vjerojatno i leži važan razlog zašto talijanski iredentizam Risorgimenta nije bio tako agresivan prema južnim Slavenima u Habsburškoj Monarhiji prije ujedinjenja Italije.

Tek će proces nacionalnog ujedinjenja Italije generirati agresivni talijanski iredentizam, koji će Istri zajamčiti konfliktnu budućnost. Do 1861. Italija nikada nije bila jedinstven politički entitet, unatoč jasno iskazanom kulturnom zajedništvu i religijskoj homogenosti. Ključna prekretnica bio je Napoleonov pobjednički pohod u Italiji 1796. - 1814., koji je stvorio prototip „Kraljevine Italije“ s centrom u Milanu ${ }^{2}$. To iskustvo s Napoleonom uvjerilo je niz važnih ličnosti među

\footnotetext{
Šepić, Dragovan, 1974. Transformacije iredentizma, Istra, 6, Pula, 9-10.

2 Mack-Smith, Denis, 1997. Modern Italy: A Political History, Ann Arbor, 6-9.
} 
Talijanima da Italija može puno dobiti od uspostavljanja snažno centralizirane vlade. No prethodno se trebalo osloboditi austrijske hegemonije u Italiji. Bečki kongres (1815.) privremeno je restaurirao austrijsku nadmoć na Apeninima, ali bilo je sve očitije da je Francuska revolucija nepovratno pokrenula nacionalistički, revolucionarni i emancipacijski val, osjećaj talijanstva - italianità, koji je snažno podržala i sve jača liberalna srednja klasa.

No kulturna i ekonomska obnova vodit će razvoju prema Risorgimentu tek nakon što niz utjecajnih osoba prione transformiranju uzvišenih ideala u konkretnu političku akciju. Republikanac Giuseppe Mazzini postaje glavni prorok Risorgimenta, s poznatim stavom da je nacionalno ujedinjenje poput religiozne dužnosti, štoviše, ono je dio Božanske Providnosti. Pojavljuje se i najveći vojskovođa Risorgimenta, Giuseppe Garibaldi, republikanac i socijalist, premda sasvim u službi Monarhije. Međutim, Mazzinijev duboki idealizam i Garibaldijeva odvažnost još nisu bili dovoljni bez postojanja jednog nukleusa, čvrste jezgre oko koje bi se okupljao ostatak Italije. Bio je to Pijemont, sa svojom ratobornom dinastijom i makijavelističkim premijerom Camillom Cavourom, koji je znao vješto uključiti talijansko pitanje u centar pažnje najjačih europskih država. Cavour je umješno iskorištavao suparništva između Engleske i Francuske, Francuske i Austrije te Austrije i Pruske nastojeći da ponekad i sam Pijemont bude jezičac na vagi u europskoj ravnoteži snaga ${ }^{3}$. Bit njegova diplomatskog umijeća bila je uvjeriti europske velike sile da Talijani znaju veoma dobro i sami sobom upravljati, bez austrijskog tutorstva kao do tada. Ukratko, ujedinjenje Italije bilo je moguće zbog veoma povoljne diplomatske situacije u Europi, sposobnosti Cavoura, avanturističkog duha Garibaldija, kao i niza drugih zbivanja i isprepletenih okolnosti i silnica u tom povijesnom razdoblju4

Posebno valja istaknuti činjenicu da je nacionalno ujedinjenje Italije bitno ovisilo o vanjskom čimbeniku - o stanju europske ravnoteže snaga. Talijanska država ujedinila se voljom europskih velikih sila koje su je podržavale zbog vlastitih interesa. Tako je V. Britanija smatrala kako je bolje da Italija bude ujedinjena nego da opet postane austrijski ili francuski vazal, čime bi mogla postati novi važan čimbenik ravnoteže u Europi. Cavour je to i naslućivao, te je sugerirao Britaniji da je u njezinu interesu stvaranje što veće Italije kao protuteže Francuskoj na Sredozemlju ${ }^{5}$. No posebno je važno bilo što o tome misli tada najjača

\footnotetext{
Mack-Smith 1997, 11-20.

4 Procacci, Giuliano, 1996. Povijest Talijana, Zagreb: Barbat, 229id.; Debidour, Antonin, 1933. Diplomatska istorija Evrope: od otvaranja Bečkog kongresa do zaključenja Berlinskog (1814-1878), knj. II, Beograd: Geca Kon, 292id.

5 Mack-Smith 1997, 24.
} 
kontinentalna sila - Francuska. Još od 1856. godine car Napoleon III. snažno se zalagao za pobjedu načela narodnosti u Europi. Dok je nekada ruski car Aleksandar I. želio utemeljiti europski ekvilibrij na „bratskom savezu monarha“, Napoleon III. maštao je o tome da ravnotežu uspostavi dogovorom i grupiranjem emancipiranih nacija, od kojih bi svaka stvorila vlastitu neovisnu državu $u^{6}$. Time je želio napokon ukloniti i posljednja ograničenja koja su potjecala još od protufrancuskog Bečkog ugovora (1815.), preustrojiti političku kartu Europe i vratiti Francuskoj „prirodne granice“ na Rajni i Alpama. Svojim stavovima Napoleon III. podilazio je talijanskom pokretu nacionalne integracije. On je sanjario o tome da pod svojim ravnanjem ujedini tzv. „latinske rase“ stvarajući golemu zajednicu koja bi obuhvaćala Francusku s Belgijom, Portugal, Španjolsku i Italiju. U takvom planu Napoleon III. vidio je prioritet u nacionalnoj unifikaciji Italije istjerujući Austrijance iz nje. Već od 1856. imao je potpun plan o oslobađanju Italije iz ruku Austrije, ali ne na način da se stvori jedna unitarna država već konfederacija kojom bi upravljao Pijemont, ali vezana za Francusku „zahvalnošću i politikom“" Napokon, francuski car želio je obnoviti francusku hegemoniju u Srednjoj Europi i mrzio je konzervativni austrijski kabinet, te se odlučio na revolucionarni savez $\mathrm{s}$ talijanskim nacionalizmom ${ }^{8}$. Upravo će tu ambiciju Napoleona III. znalački iskoristiti Cavour.

Tako se Napoleon III. na koncu sastao s Cavourom u Plombiersu 20. srpnja 1858. ${ }^{9}$, te je sada i ugovorom bila zajamčena francuska pomoć Pijemontu da istjera Austrijance s Apenina. Nakon uspješnog ratovanja protiv austrijske vojske u Italiji, prvi se talijanski parlament sastao u Torinu 18 . veljače $1861 .^{10}$ Veći dio Italije bio je ujedinjen, pa vladar Pijemonta Viktor Emanuel uzima titulu kralja Italije.

No Kraljevina Italija nije još obuhvaćala Veneciju ni Rim, u kojem je bio stacioniran francuski garnizon štiteći papinsku vlast. Stoga su se talijanske nacionalne aspiracije sada povezale s njemačkim pokretom za nacionalno ujedinjenje, predvođenim Bismarckovom Pruskom. Talijanski politički vrh vidio je povijesnu prigodu da se napokon riješi Austrije pomoću pruskog oružja. Bismarck je težio tzv. „malonjemačkom“ rješenju i izbacivanju Austrije iz njemačkih poslova. Očekivao se veliki obračun za vodstvo u Njemačkoj. Nakon bezuspješnog nagovaranja austrijskog cara Franje Josipa da mirno prepusti Veneciju Italiji, Napoleon III. napokon je dozvolio savez Pruske i Italije za vođenje rata protiv Austrije.

\footnotetext{
6 Debidour 1933, II, 243-244.

7 Debidour 1933, II, 250.

8 Taylor, Alan John Percivale, 1968. Habsburška Monarhija 1809-1918. Zagreb: Znanje, 121.

9 Potemkin, Vladimir Petrovič, 1951. Historija diplomacije; knj I, Zagreb: Matica hrvatska, 424.

10 Debidour 1933, II, 339-346.
} 
Taj savez bio je potpisan 8. travnja 1866., a cijena koju je Bismarck morao platiti bila je predaja Venecije Italiji. U tom tzv. Sedmotjednom ratu talijanska vojska bila je poražena kod Custozze, a flota kod Visa, ali će pruske snage odlučujuće poraziti Austrijance kod Sadowe (Königgrätza). Tako se Italija zapravo snagom pruskog oružja dočepala Venecije. Na venecijanskom plebiscitu (u listopadu 1866.) bilo je 647.246 glasova za ujedinjenje s Italijom, a samo 69 glasova protiv ${ }^{11}$.

Bismarck će zatim na „malonjemačkom“ programu ujediniti Njemačko Carstvo prethodno porazivši Francusku Napoleona III. (1870./71.). Francuski garnizon prisiljen je sada povući se iz Rima, te su 20. rujna 1870., unatoč protestima pape Pija IX., talijanske regularne snage umarširale u Rim. „Vječni grad“ premoćno je glasovao za aneksiju Kraljevini Italiji, te je u srpnju 1871. proglašen glavnim gradom Italije ${ }^{12}$. Papa se demonstrativno povlači u Lateransku palaču sve do 1929. godine dozvolivši Kraljevini Italiji suverenu vlast na Apeninskom poluotoku.

Opisana zbivanja na razini europske politike odrazila su se i na budućnost Istre. Naime, ujedinjenjem Italije „tuđim oružjem“ imperijalistički apetiti mlade države, i dalje poticani revolucionarnim nacionalizmom Risorgimenta i nerealnim osjećajem svemoći, bili su sve veći i postajali su prijetnja drugim teritorijima Habsburške Monarhije. Isprva tako podržana velikim silama, Italija dolazi do opasno pogrešne percepcije da je ona inherentno jaka sila te da će i nadalje biti podržana njezina teritorijalna ekspanzija. Činilo se u to vrijeme da međunarodne okolnosti izrazito pogoduju generiranju talijanskog iredentizma. Još je 1845. u glavnom stožeru Sardinijske Kraljevine bilo zaključeno kako strateške granice nove Italije moraju biti na istoku na Bitoraju, a na sjeveru pred Ljubljanom, te da moraju obuhvaćati Istru, Rijeku, Bakar, Kraljevicu, Krk, Idriju i Logatec. Tako se tijekom kampanje za nacionalno ujedinjenje Italije stvarao $u$ talijanskoj javnosti dojam da su Istra i druga područja na istočnoj obali Jadrana povijesno talijanske zemlje. Uspješnim ratovanjem protiv Austrije granice talijanske države širile su se sve do Soče. Italija tada dobiva morske i kopnene granice s habsburškom državom, te mnogi talijanski nacionalisti Risorgimenta postaju preko noći žestoki iredentisti. Na enormno jačanje talijanskog iredentizma prema teritorijima Austrije, Francuske i drugih zemalja, posebno su utjecale teze da je Italija prirodni zaštitnik antičkog Rimskog Imperija i zatim slavne Mletačke Republike ${ }^{13}$. Italija

\footnotetext{
11 Hayes, Carlton J.H., 1924/5. A Political and Social History of Modern Europe, sv.II, New York: The Macmillan Company, 174.

12 Hayes 1924/5, II, 175.

13 Strčić, Petar, 2001. Egzodus Hrvata iz Istre i drugih hrvatskih krajeva između 1918. i 1943. godine kao politička, nacionalna i gospodarska pojava; u: Talijanska uprava na hrvatskom prostoru i egzodus Hrvata (1918.-1943.), (Manin, Marino, ur.), Zagreb: Hrvatski institut za povijest: Društvo Egzodus istarskih Hrvata, 2001., 21-22.
} 
je posebno zainteresirana za dvije austrijske pokrajine - Veneziju Giuliju, u koju su spadale Istra, Trst i Goriška, te Veneziju Tridentinu, koja je obuhvaćala Trentino i Alto-Adige. Ubrzo punu afirmaciju doživljava pojam terre irredente (,neoslobođene zemlje"), koji ponajviše cilja na austrijske teritorije, te se osnivaju brojne militantne nacionalističke i iredentističke organizacije, poput Azione per Riscato u Trstu (1866.) ili L'assoziazione in pro dell' Italia irredenta (1877.) u Napulju.

Ujedinjenjem Italije i slabljenjem Austrije bilo je omogućeno prelijevanje talijanskog nacionalizma i iredentizma na Istru. Politika Italije bila je od početaka države vođena mišlju o „neoslobođenim teritorijima“, tako da je program iredentista brzo postao sastavni dio politike talijanskih vlada. Posebno nakon relativnog razočaranja koje je Italija doživjela nakon nepotpunog ujedinjenja 1866. iredentizam jača, dobiva svoje ime i organizaciju, a talijanska vlada pomaže taj pokret $^{14}$. U Istri i na kvarnerskim otocima istodobno se razvijao, s hrvatskim i slovenskim, i proces talijanske nacionalne integracije, čvrsto povezan s idejama talijanskog Risorgimenta koje su navirale s Apenina ${ }^{15}$. Proces talijanske nacionalne integracije pojavio se nešto prije nego u Hrvata, jer su Talijani Istre i Kvarnerskih otoka spremnije dočekali integracijske procese. Naime, oni su imali bolje preduvjete, izgrađenije društvene slojeve, kao i stoljetnu prevlast i dominaciju $\mathrm{u}$ obnašanju vlasti unatoč tome što su, gledano brojčano, bili u manjini. Ideje Risorgimenta implicirale su težnju za sjedinjenjem Istre s Italijom i bile su osobito prihvaćene među talijanskim intelektualcima, koji su držali da će se Hrvati i Slovenci pod utjecajem talijanske kulture talijanizirati ${ }^{16}$. O pitanju suživota s Hrvatima i Slovencima talijanski intelektualci izgradili su dva bitna stajališta. Prvo je podupirao Antonio Facchinneti, a predviđao je suživot Talijana i Slavena. Drugo stajalište zastupao je Carlo De Franceschi, i ono je pretpostavljalo postupnu asimilaciju hrvatskih i slovenskih seljaka $u$ talijansku naciju ${ }^{17}$. To drugo stajalište kasnije će, nažalost, prevladati.

U skladu s promjenom međunarodnih okolnosti, mijenja se i ranije mazzinijevsko dobrohotno mišljenje o Slavenima kod glavnih ljudi Risorgimenta 1860$\mathrm{ih}^{18}$. Tako npr. Valussi, veoma tolerantan prema Hrvatima i Slovencima u Istri do 1861., nakon ujedinjenja Italije počinje govoriti da su oni tek zaostao seoski puk,

\footnotetext{
14 Šepić, Dragovan, 1976. Istra u imperijalističkom programu Italije (do Londonskog ugovora 1915.), Pazinski memorijal, 5, 138.

15 Šetić, Nevio, 2015. Istra u 19. stoljeću; u: Dalmacija i Istra u 19. stoljeću, Koautor Trogrlić, Marko, Zagreb: Lekyam international, 2015., 170.

16 Šetić 2015, 170.

17 Šetić 2015, 171.

18 Šepić 1974, 10.
} 
rasut i razdijeljen, nesposoban da se uzdigne u narod te zapravo voljan nestati $\mathrm{u}$ talijanstvu ${ }^{19}$. Valussi sada traži da se jasno definiraju nacionalne zone Talijana i Slavena, te se zalaže da se granice Italije povuku na Triglavu, Snježniku i Učki jer su to „prirodne granice“ Italije. Za većinu ljudi Risorgimenta strateškim, „prirodnim granicama“ pripadale su Alpe, uključujući i Julijske Alpe, a u Istri bi to bilo na Učki. No svakako bi trebalo nastojati, radi sigurnosti mlade države, priključiti Italiji Južni Tirol, Gorišku, Trst i Istru. Jedan od važnih motiva bio je zahtjev za jakom strateškom granicom na istoku, uperenom protiv stvaranja velike južnoslavenske države pod vodstvom Srbije, podržavane od Rusije. Carlo Combi tvrdio je da je sporazum s južnim Slavenima moguć jedino ako Italija dobije Istru s Kvarnerom i granice na Julijskim Alpama: „Istra će tada postati isturena straža talijanske civilizacije na njenom svečanom putu Istokom. ${ }^{\prime 20}$

Bachov apsolutizam nakon revolucionarne 1848. teško je pao i narodima u Istri. V. Spinčić pisao je: „Nesnosni apsolutizam između 1849. i 1860. bio je opet pritisnuo narode, pa i naš u Istri... ${ }^{\prime 21} \mathrm{Od}$ apsolutističke represije nesumnjivo su trpjeli i Hrvati, i Slovenci, i Talijani. Naime, Bachov apsolutizam u Istri obnovio je germanizatorsku politiku koja je otežavala širenje nacionalne svijesti ${ }^{22}$. Međutim, ni razdoblje apsolutizma nije omelo Talijane da vrše pritisak da se Istra proglasi talijanskom pokrajinom. Tako se krajem 1850-ih među akterima talijanskog Risorgimenta u Istri uzdiže spomenuti Carlo Combi, koji ubrzo postaje neupitni vođa pokreta za talijanizaciju Istre. On uređuje list Porta Orientale (1857.-9.), koji je simbolički tretirao Istru kao „istočna vrata Italije ${ }^{\Perp 23}$. Istinski cilj lista bio je dokazivanje da je Istra isključivo talijanska pokrajina, kao i poticanje interesa za sudbinu Istre kod Talijana na Apeninskom poluotoku. Uz to, taj almanah odigrao je veliku ulogu u učvršćivanju iredentističkih težnji. U njemu je suvremena talijanska historiografija vidjela najbolji, $u$ rodoljubnom tonu pisani, almanah razdoblja Risorgimenta ${ }^{24}$. Combi je pozivao istarske Talijane da održavaju što uže veze s matičnom zemljom na Apeninima i da rade na eventualnom integriranju

\footnotetext{
19 Vivante, Angelo. 2002. Jadranski iredentizam, Zagreb: Dom i svijet, 68.

20 Šepić 1974, 10-11.

21 Spinčić, Vjekoslav, 1924. Narodni preporod u Istri; u: Povijest Istre (Gruber, Dane), Jastrebarsko: Braća hrvatskog zmaja, 1924., 261.

22 Šepić, Dragovan, 2004. Hrvatski pokret u Istri XIX. i na početku XX. stoljeća, Buzet: Reprezent, Zagreb: HAZU, 36.

23 Combi, Carlo, 1890. Strenina Istriana per gli'anni 1857-58-59 con la prefazione e note di Paolo Tedeschi. Capodistri; u: Narodni preporod u Istri (1860-1907.) (Cetnarowicz, Anton), Zagreb: Srednja Europa, 2014., 25.

24 Bertoša, Miroslav, 1977. Carlo Combi i njegovi pogledi na povijest Istre i etnički sastav njezina pučanstva, Pazinski memorijal, 7; u: Narodni preporod u Istri (1860-1907.) (Cetnarowicz, Anton), Zagreb: Srednja Europa, 2014., 25.
} 
Istre $\mathrm{u}$ talijansku nacionalnu državu na način da se potpuno realiziraju ciljevi Risorgimenta ${ }^{25}$. Uz njega, po svojim radikalnim stavovima o talijanstvu Istre u to se vrijeme isticao i Carlo De Franceschi. On je, kao i Combi, bio izravni izdanak „etnocentričnog mentaliteta“ ondašnje talijanske liberalne inteligencije ${ }^{26}$. De Franceschi stalno ističe i veliča „slavnu rimsku prošlost istarske pokrajine, njezine spomenike, njezine pisce i slikare, civilizaciju i talijanski osjećaj, raširen višemanje po cijeloj njezinoj površini“. Štoviše, po njemu „Istra nema nikakve veze s Hrvatskom ni s njezinim pitanjima, jer ona je izrazito talijanska pokrajina“2/27.

Poznati talijanski iredentist, rođen $\mathrm{u}$ Labinu, bio je i Tomaso Luciani. U sklopu talijanskog nacionalnointegracijskog procesa u Istri, on je u 2. polovici 19. stoljeća igrao zapaženu ulogu nastojeći svojom preporodnom aktivnosti afirmirati talijanske sastavnice istarske kulture. Combi, De Franceschi i Luciani, kao i njihovi istomišljenici iz kruga talijanske „liberalne nacionalno-nacionalističke inteligencije", nastojali su cijelu Istru, skupa s njezinim brojčano većim dijelom hrvatskog i slovenskog stanovništva, uključiti u buduću Kraljevinu Italiju, koja se već stvarala diplomatskim metodama, ali i vojnom silom ${ }^{28}$. Nakon 1855 . Luciani je, stalno pod prismotrom austrijske policije, često posjećivao Veneciju, Milano, Bolognu, Firencu i Rim, s ciljem da radi na pripremi uključivanja Istre u novu talijansku državu, osobito nakon što je pijemontski premijer Cavour potvrdio da mletačke političke odbore (comitati politici veneti) ne bi trebala zastupati jedino Venecija već i njezina nekadašnja područja. Stoga su istarski talijanski intelektualci iredentističkog usmjerenja izabrali upravo Lucianija da u Kraljevini Italiji zastupa težnje o pripajanju Venecije i Istre ${ }^{29}$. On u tom smislu uspješno djeluje u Milanu i Firenci, upravo u godinama kad se, uz pomoć međunarodnih čimbenika, pripremao rat talijanske države u nastajanju protiv Habsburške Monarhije za pripajanje Venecije i ostalih "neoslobođenih zemalja“.

$\mathrm{U}$ to doba Istra još nije bila primarna meta službene talijanske politike, te je temeljna zadaća Lucianija bila snažna promidžba za uključivanje cijele Istre u novu talijansku državu, odnosno za određivanje "istočne granice“ (confine orientale) buduće Velike Italije. Unutar krugova političkih emigranata - iredentista,

\footnotetext{
25 Combi, Carlo, 1867. Appello degli Istriani all' Italia, Padova; u: Buying and Selling the Istrian Goat: Istrian Regionalism, Croatian Nationalism and EU Enlargement (Ashbrook, John. E.), Bruxelles: P.I.E. Peter Lang, 2008., 34. 
čiji je program obuhvaćao oslobođenje sjeverne Italije u njezinim „prirodnim“ granicama od Brennera do Kvarnera, Luciani je zauzimao položaj predstavnika venetsko-istarsko-tridentske političke emigracije i bio je član Venetskog političkog odbora sa sjedištem u Torinu. Talijanski intelektualci držali su ga, poslije Carla Combija, ,najplemenitijim izrazom Risorgimenta Julijske Venecije ${ }^{/ / 30}$.

Talijanski iredentizam i praktično se aktivirao potaknut dramatičnim međunarodnim zbivanjima 1859. - 1861., u doba ratovanja Sardinije i Francuske protiv Austrije u Italiji. De Franceschi je svjedočio o tome koliku je euforiju među Talijanima u Istri izazvala vijest da je velika francusko-sardinijska eskadra u lipnju 1859. ušla u luku Malog Lošinja, zauzevši grad i istaknuvši u njemu savezničke zastave $^{31}$. Talijanski iredentisti snažno su se zalagali da u ujedinjenu talijansku državu uđe i Istra. Tako Combi 1859. staje na čelo Comitato nazionale segreto di Trieste e dell' Istria, sa zadaćom mobiliziranja istarskih Talijana za borbu za ujedinjenje Istre s Italijom. Nakon primirja u Villafranci (1859.), iredentisti razmatraju stvaranje talijanske konfederacije u čijim bi se granicama trebala naći i Venecija. Combi je stao uvjeravati vlasti nekih istarskih gradova da peticijom caru zatraže pripajanje bivše mletačke Istre Veneciji ${ }^{32}$. Iredentisti su posebno bili inducirani glasinama o mogućoj ekspediciji Garibaldija na istočnu obalu Jadrana, te su bile pojačane aktivnosti tajnih odbora i poduzimane djelatnosti duž obala Istre i Dalmacije radi podrške tom nastupu. Beč je u rujnu 1860. posebno bio uznemiren viješću o objavljivanju brošure La nazionalita Istriana u Kopru, autora Combija ili Madonizze, koja je, prema mišljenju austrijskih vlasti, bila zapravo poziv na opći ustanak talijanskog stanovništva u Istri, Dalmaciji i Trstu ${ }^{33}$. Primijećeno je da su, osobito nakon poraza Austrijanaca kod Magente i Solferina (1859.) i daljnjim dramatičnim zbivanjima na Apeninima sve do 1861., iredentisti dobivali snažan zamah. U političkoj borbi sve više prevladavaju velikotalijanske ideje i sve očitija postaje težnja istarskih Talijana da se ubrza ujedinjenje Istre s „njezinom velikom majkom ${ }^{\prime 34}$.

Sve do 1870-ih i čvršćeg Bismarckova angažmana u austrijsko-talijansku regionalnu ravnotežu, talijanske elite bile su nošene revolucionarnim i idealističkim zanosom Risorgimenta otvoreno bacajući poglede na austrijske teritorije nastanjene Talijanima. S obzirom na to da su se Britanija, Francuska i Pruska gotovo natjecale $u$ protežiranju talijanske politike uslijed uzajamnih ljubomora

\footnotetext{
30 Bertoša 2012, 362-366.

31 De Franceschi 1989, 152.

32 Cetnarowicz 2014, 26.; De Franceschi 1989, 154-155.

33 Cetnarowicz 2014, 27.

34 Bertoša 1977, 185.
} 
i strahova ${ }^{35}$, talijanske elite bile su i dalje uvjerene u iluziju o vlastitoj moći, s pogrešnim vjerovanjem da će europske sile i dalje podržavati stalnu ekspanziju Italije. Tako je predsjednik talijanskog parlamenta Ricasoli još 17. srpnja 1866. znakovito pisao ministru vanjskih poslova Viscontiju Venosti: „Nije nam potreban samo talijanski Tirol, nego i Istra. Bez Istre bit će nam Austrija uvijek gospodaricom Jadrana. To je za mene glavna točka i na tome treba inzistirati. ${ }^{136}$ Međutim, u okolnostima koje su bile umjetno stvorene i u kojima je prevladavao privid favoriziranja talijanske ekspanzije, opijeni talijanski državnici stvarali su vanjsku politiku koja je uključivala rizik da bude preambiciozna za realnu snagu mlade i još uvijek krhke države. Cilj je bio previsoko postavljen, a sposobnosti države skromne. Mazzinijevski revolucionarni idealizam potencijalno je vodio stalno novim zapletima, te se otvorena borba za moć Italije, uz njezine inherirajuće unutarnje slabosti, mogla pričiniti vladajućim elitama iracionalnom i nerazboritom solucijom. Stoga su bivši revolucionarni mazzinijevci nakon 1870. evoluirali u svojim pogledima. Više su vodili računa o slabostima mlade talijanske države osjećajući da Trocarski savez dominira u Europi te da Bismarckova tvorevina ne podnosi revolucionarna rješenja nacionalnog pitanja u Srednjoj Europi ili na Balkanu ${ }^{37}$. Tako talijanske elite postaju sve svjesnije vanjskih ograničenja svom iredentističkom nastupu prema Austriji, koja ulazi u Bismarckovu sferu utjecaja. Štoviše, 1879. zaključen je i Dvojni savez Njemačke i Austro-Ugarske.

Suočene s tim vanjskim ograničenjima, talijanske političke elite prelaze s mazzinijevske na $\mathrm{tzv}$. balbovsku poziciju u vanjskoj politici. Naime, u doba Risorgimenta u Italiji su se mogla razabrati dva temeljna stava o nacionalnom ujedinjenju zemlje. Prvo motrište bilo je demokratsko i revolucionarno, zastupano od Giuseppea Mazzinija, a drugo konzervativno i kompromisno na idejama Cesarea Balboa. Mazzinijevska demokratsko-revolucionarna koncepcija povezivala je proces ujedinjenja Italije s borbom protiv Austrije i trijumfom revolucionarnog načela narodnosti, dok je Balbova konzervativna doktrina zahtijevala ujedinjenje Italije na način da postojeći europski poredak ostane očuvan i dalje održavan preko tradicionalne europske diplomacije te kompenzacijama uime održavanja ravnoteže snaga ${ }^{38}$.

Sedamdesetih godina 19. stoljeća vanjska politika Kraljevine Italije mijenja se pod utjecajem međunarodne politike, s jasnim refleksijama na pitanje Istre.

\footnotetext{
35 Mack-Smith 1997, 108-109.

36 Marjanović, Milan: Londonski ugovor iz godine 1915.: prilog povijesti borbe za Jadran 1914.-1917, Zagreb: JAZU, 76.

37 Šepić, Dragovan, 1978. Talijanski iredentizam i istočna kriza 1875-1878, Istra, 5-6, 106.

38 Šepić 2004, 273.
} 
Kraljevina Italija će, stiješnjena između dvije velesile - Francuske i Njemačke, prakticirati staru vanjsku politiku Pijemonta u kojoj je njezina podrška nekoj od velikih sila mogla biti precjenjivana iznad njezine realne vrijednosti. Takav pivotalni položaj talijanske države ponekad se promatrao u smislu jezičca na vagi europske ravnoteže. Vođena tim načelima, talijanska će politika od tada nadalje fleksibilno mijenjati svoje lojalnosti nastojeći da se pravovremeno priključuje pobjedničkoj strani. Ona vodi više računa o ravnoteži snaga i ponekad se doima neangažiranom. Tako su se prije nastupa na položaju premijera imperijalistički usmjerenog Crispija (1887.-91. i 1893.-96.) i desnica i ljevica u talijanskoj državi prešutno suglasile da će „igrati na sigurno“. Npr. ministar vanjskih poslova desnice, Visconti-Venosta, inzistirao je na tome da Italija ostane "neavanturistička" država; Cairoli je na ljevici vjerovao u politiku „slobodnu od obveza“, dok je lijevi premijer Depretis (od 1876.) čak držao vanjsku politiku „,dosadnom ${ }^{\prime \prime 39}$. Štoviše, pod Minghettijem dolazi do približavanja između Italije i Austrije i to će naizgled nevjerojatno približavanje "hereditarnom neprijatelju“ biti nastavljeno i u idućih 40-ak godina. Razlog tom naizgled nelogičnom talijanskom približavanju Austriji ležao je u teškom porazu Francuske Napoleona III. u ratu protiv Pruske (1870./71.) i posljedičnom naginjanju europske ravnoteže u korist ujedinjene Njemačke nakon 1870. Prvi Trocarski savez (1873.) i Dvojni savez (1879.), pa zatim i Drugi Trocarski savez (1881.), jasno su govorili talijanskim državnicima da je Bismarckova Njemačka "gazda" u Europi te da Italija do daljnjega ne može realno naškoditi Austriji. I premda su preostale latentne iredentističke struje u talijanskoj politici koje su i dalje zagovarale rušenje regionalne ravnoteže u mazzinijevskom revolucionarnom stilu, te rat protiv Austrije za pripajanje Trenta, Trsta i Istre, realističniji talijanski političari odbacivali su nasilnu opciju opredijelivši se za pridruživanje Italije nadmoćnoj sili - Njemačkom Carstvu.

Kada je Crispi posjetio Bismarcka (IX. 1877.), njemački ga je kancelar uputio na to da se treba miriti s Austrijom i da ne pomišlja na Trentino ili Trst. Uputio ga je na traženje kompenzacija na Istoku: „Ako Austro-Ugarska uzme Bosnu i Hercegovinu, neka Italija uzme Albaniju ili koju drugu tursku pokrajinu..$^{1 / 40}$. Ministar vanjskih poslova Austro-Ugarske, Andrassy, čak je zaprijetio Italiji ako bude i dalje pretendirala na Tirol, Trst, Istru i druge teritorije. On je talijanski politički vrh stavio pred dilemu: ili će Italija ići zajedno s Austro-Ugarskom, kada se mora potpuno odreći svih težnji za habsburškim teritorijima na kojima obitavaju Talijani; ili će Italija krenuti protiv Austro-Ugarske, no tada će habsburška

\footnotetext{
39 Mack Smith 1997, 111

40

Marjanović 1960, 13.
} 
država prvom prigodom napasti Italiju i revidirati granicu u vlastitu korist ${ }^{41}$. Andrassy je Italiji ukazao na koristi koje može imati ako odustane od nasrtaja na habsburške zemlje i postane partner Carevine. Prije svega, Italija može pronaći kompenzacije na Istoku, u Tunisu ili negdje drugdje daleko od „neoslobođenih zemalja", što bi Austro-Ugarska podržala.

Upravo će tu ideju dalje razvijati Bismarck, kada na predstojećem Berlinskom kongresu (1878.) bude nagovarao Italiju da zauzme Tunis, s prikrivenim planom da je uvuče u savez s Centralnim silama protiv Francuske. Nemoćna pred vojnom moći i ugledom Bismarckove Njemačke, Italija se pomirila s time da ne može više "igrati“ na sporove i opreke između Njemačke i Austrije, ili Francuske protiv Njemačke, pa tako ni na Berlinskom kongresu nije imala snage nametnuti svoj utjecaj silama. Suočen sa stvarnošću na tom kongresu, talijanski politički vrh odlučuje se približiti Njemačkoj. Balbova vanjskopolitička koncepcija bit će konačno afirmirana upravo ulaskom Italije u Trojni savez (1882.) s Njemačkom i Austro-Ugarskom i od tada će se talijanske vlade uglavnom ponašati suzdržano, taktički i dvolično u odnosu na Dvojnu monarhiju. U zamjenu za veoma mutne i sumnjive dobitke, Italija se obvezala da će odbaciti sve iredentističke zahtjeve prema Austro-Ugarskoj ${ }^{42}$. Tako primjerice talijanski premijer Depretis nakon 1882. nije više dozvoljavao da mu iredentisti narušavaju naglo poboljšane odnose s Austro-Ugarskom. On će raspustiti sve iredentističke organizacije u Italiji, premda će poštedjeti sam pokret ${ }^{43}$.

Upravo je to bilo znakovito za daljnju politiku Kraljevine Italije prema Austro-Ugarskoj Monarhiji. Naime, talijanski iredentizam nije iščeznuo, već se nastavio širiti Istrom i Julijskom krajinom prikrivenim sredstvima i kanalima. $S$ obzirom na to da je Trojni savez sada isključivao otvoren iredentistički nastup službene Italije prema habsburškim teritorijima, talijanske vlade neće više otvoreno poticati i podržavati talijanizaciju Istre, ali će to činiti potajno. Tako talijanska vlada, premda javno osuđuje iredentizam, ipak tajno pomaže djelovanje iredentističkih društava koja rade na širenju talijanstva u Tirolu, Goriškoj, Trstu i Istri ${ }^{44}$. Talijanske vlade sada djeluju u Istri preko tajnih službi i različitih udruga i stranaka. U Trstu je 1886. utemeljeno društvo Pro Patria sa zadaćom osnivanja talijanskih škola i širenja talijanske nacionalne svijesti u Istri ${ }^{45}$. Zbog

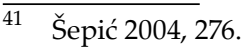

42 Mack Smith 1997, 114.

43 Novak, Bogdan, 1970. Trieste 1941-1954: The Ethnic, Political and Ideological Struggle, London, Chicago: The Univ. of Chicago Press, 16.

44 Šepić 1974, 11-12.

45 Tumpić, Dušan, 1993. Hrvatska Istra, Zagreb: Alinea, 57.
} 
protuaustrijskih stavova, to jsue društvo austrijske vlasti zabranile 1890., ali je već 1891. obnovljeno pod imenom Lega Nazionale. Indikativno je bilo da je ono financirano sredstvima koja je u Italiji prikupljalo društvo Dante Alighieri. Hrvati i Slovenci smatrali su društvo Lega nazionale glavnim instrumentom talijanizacije slavenskog stanovništva u Julijskoj krajini ${ }^{46}$. Uz to, Talijanska nacionalno-liberalna stranka bila je pripravna odlučno prevenirati bilo kakvu zakonsku najavu ravnopravnosti Hrvata i Slovenaca i protivila se svakoj političkoj mjeri države koja bi Hrvate i Slovence dovela u ravnopravan položaj s Talijanima u Istri ${ }^{47}$.

Poticana dvosmislenom politikom talijanskih vlada - koje su se, s jedne strane, javno odricale iredentizma, a s druge ga potajno podržavale - ta je stranka u Istri, Trstu i Goriškoj formalno surađivala s austrijskom vladom, istodobno suzbijajući narodni pokret Hrvata i Slovenaca, oslanjajući se na svoj povlašteni položaj. Talijanska liberalna stranka vidjela je sada, umjesto Austrije, upravo Hrvate i Slovence, nacionalno i politički osviještene, kao glavne neprijatelje talijanstva, te čak počinje smatrati da je Austro-Ugarska nužna i korisna brana protiv tzv. „slavenske opasnosti“48. Tipična je bila dvosmislena politika talijanskog premijera Crispija. On je bio s jedne strane žestoki zagovornik Trojnog saveza i javno se odricao iredentizma prema Austriji. Crispi se uzdao u neupitnu vojnu nadmoć Njemačke sanjareći o zajedničkom prodoru Italije s Centralnim silama na Balkan na štetu Slavena, te je 1889., da bi ugodio Austro-Ugarskoj, čak raspustio rimski „Komitet za Trento i Trst". No s druge strane, Crispi ipak nije prestao davati novčane potpore iredentistima preko tajne službe. On se privatno nadao da će se austrijski imperij jednoga dana raspasti na korist Italije, premda nije precizno vremenski anticipirao takva zbivanja ${ }^{49}$.

Premda je sada bila u Trojnom savezu, Kraljevina Italija sa zavišću je pratila ekspanzionističke težnje Dvojne Monarhije na Balkanu i osigurala se $\mathrm{u}$ članku 7. Trojnog saveza da za svako njeno širenje na tom poluotoku dobije teritorijalne kompenzacije ${ }^{50}$. Preciznije, članak 7. govorio je o tome da je u slučaju promjene statusa quo na Orijentu, Balkanu, obali Otomanskog Carstva te egejskim i jadranskim otocima potpisnicama predviđena određena kompenzacija ${ }^{51}$. Bismarckov cilj bio je postignut: slično održavanju austro-ruske ravnoteže na Balkanu pod njegovim

\footnotetext{
$\overline{46 \quad \text { Novak } 1970,16 .}$

47 Dukovski, Darko, 2004. Istra: kratka povijest dugog trajanja: od prvih naseobina do danas, Pula: Istarski ogranak DHK, 111.

48

Šepić 1974, 12.

49 Mack Smith 1997, 132-133.

50 Šepić, Dragovan, 1975a. Jadransko pitanje od 1915. do 1954., Istra, 1-2, Pula, 17.

51 Kardum, Livia, 2000. Europska diplomacija i Prvi svjetski rat, Zagreb: FPZ, 89.
} 
nadzorom, uspostavljena je i relativno dugoročna ravnoteža između Austro-Ugarske i Italije na Jadranu. Ona je bila potkrepljivana stalnim produživanjem ugovora o Trojnom savezu (1887., 1892., 1902., 1907., 1912.) $)^{52}$. Ta europska stvarnost kočila je otvorenu manifestaciju iredentizma Kraljevine Italije prema habsburškim teritorijima u razdoblju od 1882. do početka 20. stoljeća. No tada nastupa novi obrat. Međunarodna politika početkom 20. stoljeća ponovo je inducirala talijanski iredentizam, koji je sada bio povezan sa širim imperijalističkim programom. Uz „neoslobođene teritorije" u Austro-Ugarskoj Monarhiji, meta postaju i osmanske zemlje. Prvi važan događaj bio je kolonijalni neuspjeh Italije u Africi. Petnaestak su godina talijanske vlade, uz podršku Centralnih sila, bacale poglede na kolonijalne teritorije, što je posebno podržavao imperijalistički usmjeren premijer Crispi. Međutim, talijanska kolonijalna vojska doživljava pravu katastrofu u bitci kod Adue (1896.), kada su Crispijeve kolonijalne ambicije bile krvavo srušene pod kopljima etiopskih domorodaca. $S$ obzirom na to da tada više nije bilo Bismarcka i njegove uravnotežujuće politike, talijanski imperijalistički program ponovo se okreće prema Jadranu i austro-ugarskim teritorijima.

No drugi proces bio je još dramatičniji - Italija se ponovo približava Francuskoj, na užas Centralnih sila. Austro-Ugarska počinje sumnjičavo gledati na namjere Italije, koja postaje najslabija karika Trojnog saveza. Posljedica tog procesa bilo je novo bujanje talijanskog iredentizma, te austrijski ministar vanjskih poslova Goluchowski priopćuje njemačkom poslaniku 20. listopada 1903. sljedeće: „Da sam samo slutiti mogao, da će iredentizam i protuaustrijsko raspoloženje u Italiji u novije vrijeme uzeti toliko maha, nikad ne bih pristao na produženje ugovora s Italijom. ${ }^{.53}$ Zatim je Aneksijska kriza (1908./09.) prilično ogoljela pravo stanje stvari. Kada je Austro-Ugarska nakon aneksije Bosne i Hercegovine započela s većom aktivnošću na Balkanu, Kraljevina Italija to je doživjela kao izazov $^{54} \mathrm{i}$ kao očito kršenje klauzule o uzajamnim kompenzacijama te narušavanje ravnoteže snaga. Te promjene međunarodnih okolnosti rezultirale su daljnjim razbuktavanjem talijanskog iredentizma, posebno u pograničnim područjima između Italije i Austro-Ugarske. Kao što je poznato, Trojni savez ipak je obnovljen 1912. iz poznatih taktičkih razloga, a podijeljeno i sukobljeno stanovništvo Istre u konfliktnom je stanju dočekalo izbijanje Prvog svjetskog rata.

\footnotetext{
Marjanović 1960, 13-20.

Marjanović 1960, 15.

54 Toševa-Karpowicz, Ljubinka, 2007. D’Annunzio u Rijeci: mitovi, politika i uloga masonerije, Rijeka: Izdavački centar Rijeka, 19.
} 


\section{Proces nacionalne integracije istarskih Hrvata $u$ otporu iredentizmu $i$ talijanizaciji}

Kao što smo već istaknuli, u zemljopisnoj se Istri u drugoj polovici 19. stoljeća zbivao gotovo istodobno proces nacionalne integracije Talijana, Hrvata i Slovenaca, s konfliktnim implikacijama. Konfliktna narav talijanskog Risorgimenta u Istri, procesa koji je inzistirao na talijanizaciji poluotoka i njegovu pripajanju Italiji, predstavljala je bitan unutarnji uzrok istarskih sukobljavanja u drugoj polovici 19. stoljeća.

Opće je poznato kako proces hrvatske nacionalne integracije odgovara istovjetnim procesima $u$ Europi toga doba. Nacije su se svojim obuhvatom definirale integrirajući one pojedince i grupe koji su mogli osjetiti privlačnost, ili barem ne osjećati otpor prema određenom nacionalnom identitetu, te dosežući svoje granice upravo u doticaju s onima koji su bili pogodni da se odazovu atraktivnosti identiteta nekih drugih integracijskih jezgara. Proces nacionalne individualizacije bio je stoga istodobno proces diferencijacije, a proces integracije bio je istodobno i proces separacije ili razgraničenja ${ }^{55}$. U etničkim nacionalizmima, „nacionalnost" postaje sinonim „etniciteta“. Stoga je nacionalni identitet često bio percipiran kao odraz ili svjesnost o posjedovanju „primordijalnih“ ili inherentnih grupnih karakteristika, sastavnica „etniciteta“, kao što su jezik, običaji, teritorijalna afilijacija i psihički tip ${ }^{56}$. Distinktivnost nacionalnih identiteta tako postaje važna činjenica, a s time i njihov konfliktni potencijal, posebno ako se različiti procesi nacionalne integracije odigravaju na istom, spornom teritoriju. Upravo to je bio slučaj na Istarskom poluotoku u 19. stoljeću. Na kojem su veliku većinu činili Hrvati i Slovenci u odnosu na Talijane.

Pod pojmom „integracija“ hrvatske nacije, Mirjana Gross razumije kompleksni proces preobrazbe tradicionalne hrvatske etničke zajednice, odnosno srednjovjekovnoga hrvatskog naroda, u modernu naciju tijekom 19. i 20. stoljeća. Koncept „integracija“ izražava neravnomjeran tijek oblikovanja hrvatske nacije $\mathrm{u}$ pojedinim područjima s različitim društvenim strukturama i ekonomskim, političkim, upravnim i kulturnim uvjetima ${ }^{57}$.

55 Stančić, Nikša, 2002. Hrvatska nacija i nacionalizam u 19. i 20. stoljeću, Zagreb: Barbat, 50.

56 Greenfeld, Liah, 1992. Nationalism: Five Roads to modernity, Cambridge, Mass.; London: Harvard University Press, 12.

57 Gross, Mirjana, 1981. O integraciji hrvatske nacije, u: Društveni razvoj u Hrvatskoj: (od 16. stoljeća do početka 20. stoljeća) (Gross, Mirjana, ur.), Zagreb: Sveučilišna naklada Liber, 175. 
Proces nacionalne integracije prema modelu M. Hrocha ${ }^{58}$, koji je hrvatskim okolnostima prilagodila M. Gross ${ }^{59}$, iskazuje tri, odnosno četiri temeljne faze nacionalne integracije: inicijalnu fazu; središnju ili odlučnu fazu; razdoblje stagnacije ili međufazu; te završnu fazu ${ }^{60}$. Model je posebno pogodan za primjenu na male ili „potlačene" nacije, kako kaže M. Hroch, kojima je u povijesti pripadala i Hrvatska ${ }^{61}$.

Faza A, inicijalna faza, ona je u kojoj su neki pisci nesustavno iznosili ideje koje će postupno zadobivati mobilizatorsku ulogu u procesu nacionalne integracije. Faza B je središnja ili odlučna etapa, u kojoj skupina rodoljuba sastavljena od pripadnika određenih društvenih slojeva i profesionalnih grupa, preko raznih institucija, sustavno i organizirano vrši nacionalnu propagandu. Ona isprva obuhvaća samo uži krug, zatim se širi na više klase, da bi se kasnije proširila i na šire slojeve nacije u nastajanju. $U$ fazi $C$ može se smatrati da je proces nacionalne integracije uglavnom dovršen, s obzirom na to da se pretežita većina nacije može mobilizirati u borbi za ekonomske, socijalne, političke i kulturne oblike života, potrebne afirmaciji neke nacije, a većina pripadnika nacije, sada nacionalno osviještena, ima sposobnost sudjelovanja u masovnom nacionalnom pokretu ${ }^{62}$.

$\mathrm{U}$ hrvatskom procesu nacionalne integracije nalazimo fazu A, u što bi se moglo uključiti brojne pisce od renesanse do kraja 18. stoljeća, zaslužne za početke izgradnje nacionalne ideologije. Središnja faza hrvatske nacionalne integracije, faza B, prepoznata je kao razdoblje Hrvatskog narodnog preporoda. Bila je to etapa u kojoj je jezgra rodoljuba, koja je konzistirala od svećenstva, inteligencije i građanstva, sustavno i organizirano širila nacionalnu svijest te mobilizirala ljude za akciju u svrhu integriranja hrvatske nacije. Ilirski pokret bio je najvažnija komponenta Hrvatskog narodnog preporoda. Različite brzine i tipovi kretanja prema hrvatskoj nacionalnoj integraciji, u uvjetima separiranih i zasebnih ekonomskih i političkih jedinica, otežavali su prijelaz iz preporodne faze u razdoblje masovnog nacionalnog pokreta, fazu C, čime bi se proces hrvatske nacionalne integracije u Istri mogao smatrati dovršenim. Stoga je M. Gross držala da je potrebno između faze $\mathrm{B}$ i faze $\mathrm{C}$ umetnuti prijelazno razdoblje. Tako je $\mathrm{u}$ Istri i $\mathrm{u}$ Bosni i Hercegovini, gdje su jezgru preporoditelja inicijalno činili svećenici, proces nacionalne integracije u Hrvata bio postupniji, i zapravo ponešto drugačiji.

\footnotetext{
58 Hroch, Miroslav, 1979. Oblikovanje modernih nacija i nacionalni pokreti 19. stoljeća, Časopis za suvremenu povijest, 1, 23-40.

59 Gross 1981.

60 Gross 1981, 183-186.

61 Hroch, Miroslav, 2006. Društveni preduvjeti nacionalnih preporoda u Europi: komparativna analiza društvenog sastava patriotskih grupa malih europskih nacija, Zagreb: Srednja Europa, 37-38.

62

Gross 1981, 183.
} 
Iz tog se razloga u Istri i Bosni i Hercegovini nije moglo govoriti o izrazitoj fazi masovnog pokreta prije $1918 .^{63}$

Nakon raspada Austro-Ugarske nakon Prvog svjetskog rata sve su hrvatske zemlje nakratko ujedinjene u Državi Slovenaca, Hrvata i Srba. Uslijed njezinih ekonomskih problema i prijetnje talijanske okupacije obale ${ }^{64}$, ta se država brzo ujedinila sa Srbijom i Crnom Gorom u Kraljestvo Srba, Hrvata i Slovenaca, kasnije tzv. prvu Jugoslaviju. Bez obzira na njezin nedemokratski karakter, Hrvati su u njoj nastavili zajednički živjeti, s izuzetkom Istre, Kvarnerskih otoka, Lastova, Palagruže i Zadra, koji su pripali Italiji ${ }^{65}$. Nakon 1945. Istra postaje i faktično sastavni dio Republike Hrvatske u ondašnjoj Jugoslaviji. Međutim, s obzirom na zbivanja 1945. - 1990., može se primijetiti da je to bila još jedna međufaza u integraciji hrvatske nacije u Istri, ali i u cijeloj Hrvatskoj, koju je obilježavalo razno dezintegracijsko i čak antiintegracijsko djelovanje. Stoga se može zaključiti da završna faza procesa hrvatske nacionalne integracije, pa onda i u Istri, nastupa u vrijeme demokratskih promjena 1990. i u zbivanjima 1990-ih, sa stvaranjem moderne i samosvojne države Republike Hrvatske ${ }^{66}$. Sličnu nacionalnointegracijsku sudbinu imali su i drugi europski narodi nakon uklanjanja socijalističkog poretka, te su njihove nacionalne države uskrsnule nakon pada Berlinskog zida (1989.) i ponovnog ujedinjenja Njemačke (1990.). ${ }^{67}$

\subsection{Uzroci konflikta tijekom procesa nacionalne integracije istarskih Hrvata}

Prostor Istre u vremenu nacionalnointegracijskih procesa, osobito od sredine 19. do sredine 20. stoljeća, bio je područje netrpeljivosti i sukobljavanja, premda ne treba zanemariti ni realne pokušaje skladnog života različitih naroda na poluotoku. Otežavajuća okolnost bila je u tome što se sve to zbivalo u razdoblju ustrajne borbe triju naroda u Istri - hrvatskog, slovenskog i talijanskog - za pravo na vlastito samoodređenje ${ }^{68}$. Problem je bio u tome što se teorija o suverenitetu naroda u tom području dugo osporavala ${ }^{69}$. Talijanska strana tvrdila je kako

\footnotetext{
63 Gross 1981, 183-185.

64 Holjevac, Željko (ur.), 2012. 1918. u hrvatskoj povijesti: zbornik, Zagreb: Matica hrvatska

65 Šetić, Nevio, 2005. O povezanosti Istre s ostalim hrvatskim zemljama: Naša sloga 1870.-1915., 2.izd., Zagreb: Dom i svijet, 55-56.

66 Šetić 2005, 56-57.

67 Šetić, Nevio, 2017. Ostvarenje suvremene hrvatske države: od pojave višestranačja 1989. do nastanka samostalne, međunarodno priznate i teritorijalno cjelovite Republike Hrvatske, 2.izd., Zagreb: Družba „Braća Hrvatskoga Zmaja“.

Šetić 2005, 15.

69

Bertoša 1985.
} 
je talijanski nacionalizam u Istri nastao kao „prirodni“ fenomen, usko povezan s težnjom Talijana na Apeninskom poluotoku da stvore jedinstvenu nacionalnu državu, a bio je nošen zajedničkim idealima kao posljedica duhovnog zajedništva svih Talijana. Stoga se držalo da pojava talijanskog nacionalizma u Istri ima opravdanje u povijesti zemlje i nadmoćnoj kulturi gradskog stanovništva ${ }^{70}$, koje je uglavnom bilo talijansko. Nasuprot tome, za hrvatski i slovenski nacionalizam u Istri talijanska strana tvrdila je da je unesen izvana uz pomoć austrijskih vlasti kako bi bio instrumentaliziran protiv talijanskog nacionalnog preporodnog pokreta na Istarskom poluotoku. Međutim, ta teza s konfliktnim implikacijama nije bila sasvim točna, jer su izvori hrvatske preporodne svijesti u Istri bili puno dublji i složeniji. Hrvatski narodni pokret $u$ Istri temeljio se na trima bitnim načelima - političkom jedinstvu svih hrvatskih društvenih slojeva i skupina, zajedničkoj političkoj borbi Hrvata i Slovenaca s Talijanima u pokrajini, kao i bliskoj povezanosti i oslanjanju Hrvata Istre na bansku Hrvatsku i druge hrvatske zemlje, prije svega Dalmaciju ${ }^{71}$.

Mijo Mirković govorio je o unutarnjim i vanjskim čimbenicima koji su utjecali na uspon narodne svijesti u Istri i Dalmaciji. Kao unutarnje čimbenike on ističe: prvo, vjeru naroda u sebe i vrijednosti koje je stvorio; drugo, osnovne narodne vrednote bile su: vlastiti samostalni red na selu, na općinskim putevima, pašnjacima, šumama, na općinskom moru, u crkvi i upravi selom, red kakav je bio propisan Istarskim razvodom i Poljičkim statutom, za koje narodni slojevi nisu znali, ali su se adekvatno ponašali jer su ih na to iznova svakodnevno upućivale životna nužda i zakonitost života; treće, privremeni napredak i uspon u razdoblju 1862. - 1914. na istarskom selu i u istarskom narodu, što je stvaralo bolju podlogu za kretanje ljudi, individualni uspon, za osjećaj samostalnosti i neovisnosti seljaka, za kulturni razvitak i osobito za političke borbe; četvrto, i za Dalmaciju i za Istru bila je važna pobjeda narodnjaka na izborima za Dalmatinski sabor u Zadru već 1870.; peto, „duboko, pravo, stoljetno, prastaro osjećanje pripadnosti slavenstvu i slavenskoj uzajamnosti“72.

Tome bi se mogao pridodati kao važan i čimbenik teritorijalnog kontinuiteta nastanjenosti, s obzirom na to da je dio istočne Istre do Raše bio u doba narodnih vladara u sastavu hrvatske srednjovjekovne države. Uopće, teritorijalni kontinu-

$\overline{70}$ Rojnić, Matko, 1949. Nacionalno pitanje u Istri 1848-1849.: Historijski zbornik, 2, 79.

71 Šetić, Nevio, 2005.(b) Razmatranje tijekova hrvatske nacionalne integracije u Istri, Časopis za suvremenu povijest, 3,814 .

72 Mirković, Mijo, 1962, O sadržaju i smislu narodnog preporoda u Istri (1861-1914.). Jadranski zbornik 5, Rijeka-Pula, 31-32; Mirković, Mijo, 1969, O smislu i sadržaju narodnog preporoda u Istri, u: Hrvatski narodni preporod u Dalmaciji i Istri: zbornik (Ravlić, Jakša, ur.), Zagreb: Matica hrvatska, 1969, 286-287. 
itet nastanjenosti Hrvata i Slovenaca od zapadne obale Istre pa sve do sjevernih i istočnih granica Slovenije i Hrvatske nije nikada u povijesti bio prekinut ${ }^{73}$.

Posebno su zanimljivi „,vanjski elementi“ koji su utjecali, po Mirkoviću, na uspon narodne svijesti u Istri i Dalmaciji ${ }^{74}$.

Prvo, bio je to sudbonosan poraz Austrije u ratu s Bismarckovom Pruskom (1866.), kojim je poremećena ravnoteža snaga u Srednjoj Europi, a Austrija je, prognana iz Njemačke konfederacije, morala pomaknuti težište svoje vanjske politike prema jugoistoku Europe. Bismarck preporučuje habsburškom dvoru podjelu vlasti s mađarskim političarima radi stabiliziranja države, te Nagodbom iz 1867. nastaje Austro-Ugarska. Novokonstituirani dualizam postaje djelotvorna politika vladajućih elita Dvojne Monarhije za kontroliranje pobuđenih nacionalizama slavenskih masa unutar države - Čeha, Slovaka, Poljaka, Ukrajinaca, Slovenaca, Hrvata. Time je bio potaknut dugo potiskivani nacionalni sukob, koji će austrijske i mađarske vlasti nastojati do Velikog rata nadzirati politikom „podijeli pa vladaj”, u kombinaciji s represijom. Ono što je posebno važno bila je činjenica da u Austriji nakon 1866. Slaveni nisu više manjina već protuteža Nijemcima u Carevini. To je značilo da se i za Hrvate otvaraju nove mogućnosti u nacionalnom i emancipacijskom smislu;

Drugo, poraz Austrije u kopnenom ratu s Italijom (1866.) prisilio ju je na teritorijalne ustupke Italiji, te se između dvije države stvara granica na donjoj Soči koja istrajava pola stoljeća. Austrija popušta Talijanima u Istri, međutim istodobno u svojoj politici prema Hrvatima i Slovencima u Istri vodi računa o tome da granicu prema Italiji mogu najbolje braniti južni Slaveni ${ }^{75}$. Može se reći da je time postavljena pozornica za nacionalne sukobe i na istarskom području;

Treće, relativno mirna egzistencija Austro-Ugarske u europskom sustavu ravnoteže snaga i pod zaštitničkim okriljem Njemačke, omogućila je dugotrajni opći razvitak znanosti, gospodarstva i kulture unutar države. U taj opći razvoj bila je uvučena i Istra, a za nju je posebno važno bilo stvaranje rudimentarnog hrvatskog građanstva, osobito u pomorstvu i turizmu istočne Istre, kao nužnog čimbenika u daljnjem jačanju hrvatske narodne svijesti na poluotoku;

Četvrto, opći napredak prirodnih i društvenih znanosti, filozofije, povijesti, književnosti i dr. utjecao je na snažno jačanje svijesti o vrijednosti samonikle kulture Hrvata u Istri.

Jačanje hrvatske nacionalne svijesti u istarskih Hrvata impliciralo je sukob s agresivnim talijanskim nacionalizmom koji se prelijevao s Apenina.

\footnotetext{
$\overline{73}$ Bratulić, Vjekoslav, 1969, Političke stranke u Istri za vrijeme Narodnog preporoda, u: Hrvatski narodni preporod u Dalmaciji i Istri: zbornik (Ravlić, Jakša, ur.), Zagreb: Matica hrvatska, 1969, 289id.

74 Mirković 1962, 31-32; Mirković 1969, 286.

75 Šepić 2004, 58.
} 
Imajući na umu Hrochov model procesa nacionalne integracije, prilagođen hrvatskim uvjetima od Mirjane Gross preko Dragovana Šepića do Nevija Šetića, možemo zaključiti da je tijekom 19. i 20. stoljeća nacionalnointegracijska misao Hrvata u Istri izgrađivana kao dio jedinstvenoga hrvatskog nacionalnointegracijskog procesa, unatoč uočenim usponima, padovima i stagnacijama ${ }^{76}$. Inicijalna faza nacionalne integracije Hrvata u Istri (faza A) bilo je razdoblje od 1830ih do 1860-ih, kada su postavljeni temelji organiziranom nacionalnom pokretu. Prvu etapu, u 1830-ima i 1840-ima, obilježavao je prodor ilirskih ideja iz banske Hrvatske među istarske Hrvate. Tek je Ilirski pokret u Hrvatskoj jače djelovao na buđenje nacionalne svijesti istarskih Hrvata, a zatim i revolucionarni duh $1848 .{ }^{77}$. U otporu talijanizaciji, sve do 1860 ., pa i kasnije, prednjačili su hrvatski i slovenski svećenici u Istri kao jedine obrazovane osobe koje se nisu u školama odnarodile ${ }^{78}$. Velik odjek na narodni pokret na poluotoku imalo je djelovanja bana Jelačića u revolucionarnoj 1848., koji je u kratkom vremenu uspio okupiti gotovo sve hrvatske zemlje od Drave i Međimurja do Boke kotorske i od ušća Save u Dunav do Jadranskog mora, premda unutar Habsburške Monarhije. No izvan Hrvatske ostali su Istra i Kvarnerski otoci. Kada je imenovan za bana Trojedne Kraljevine, Jelačić se postavio na politička stajališta Hrvatskog narodnog preporoda, koja su već bila formulirana u „Narodnim zahtijevanjima“ (25. ožujka 1848.), dostavljena kralju Ferdinandu V. Bit „Narodnih zahtijevanja“, između ostalog, odnosila se na zahtjev za teritorijalnom cjelovitošću hrvatskih zemalja povratak Dalmacije s otocima te Istre i Kvarnera, kao i hrvatsko-slavonske Vojne krajine pod vlast Hrvatskoga sabora i bana ${ }^{79}$. Dakle, pitanje je bilo pokrenuto, ali $\mathrm{u}$ to doba zahtjev za Istrom nije još bio jasnije formuliran ${ }^{80}$.

U drugoj etapi te inicijalne faze nacionalne integracije istarskih Hrvata već je očit osmišljeniji rad pojedinih rodoljuba na ostvarivanju nacionalnih ciljeva. Premda se druga etapa odvijala 1850-ih, u vrijeme Bachova apsolutizma, od kojega su trpjeli represiju svi narodi u Istri, proces je nastavljen, te je ilirska ideologija i dalje prodirala u Istru, posebno s riječkog područja i iz Trsta. No u to doba talijanizacija poluotoka još nije nailazila na značajan otpor Hrvata i Slovenaca.

\footnotetext{
76 Šetić, Nevio, 1993. O procesu nastanka suvremene hrvatske nacije u Istri: skica za buduća istraživanja, Društvena istraživanja, 4-5 (6-7), Zagreb, 587-605; Šetić 2015.

77 Milanović, Božo, 1991. Hrvatski narodni preporod u Istri, knj.I, 2.izd., Pazin: Istarsko književno društvo „Juraj Dobrila“, 181.

78 Milanović 1991, 181.

79 Szabo, Agneza; Labus, Alan 2012, Hrvatska povijest: odabrane teme, Zaprešić: Visoka škola za poslovanje i upravljanje s pravom javnosti „Baltazar Adam Krčelić“, 187-188.

80

Šepić 2004, 34.
} 
U tom pogledu prekretnica će biti središnja ili odlučna faza nacionalne integracije istarskih Hrvata (1861. - 1907.), kada se oni u otporu talijanizacije čvršće udružuju s pokretom istarskih Slovenaca. Prema Neviju Šetiću, središnja faza imala je tri etape: prvu u 1860-ima, drugu 1870. - 1882. i treću 1882. - 1907. godine $^{81}$. Kada je 1861. Istra dobila Pokrajinski sabor u Poreču, odmah se zaoštrila politička borba između, s jedne strane, Talijana te, s druge, Hrvata i Slovenaca na cijelom poluotoku ${ }^{82}$. Od 1861. Istra se napokon počinje razvijati, ali tom će prosperitetu veoma smetati nacionalna borba između Talijana te Hrvata i Slovenaca ${ }^{83}$, uza sve veće jačanje iredentističkog pokreta Talijana u austrijskim zemljama, kao pokreta za priključenje Goričke grofovije, Istre i Trsta Italiji ${ }^{84}$. U Pokrajinskom saboru Hrvati i Slovenci nisu bili u ravnopravnom položaju ${ }^{85}$. Kurijalni sustav biranja povlašćivao je bogatiji društveni sloj, a to su tada bili Talijani. Tako je na prvim izborima za Pokrajinski sabor (ožujak 1861.) pobijedila Talijanska liberalna stranka s 21 mandatom, talijanski konzervativci dobili su 4, a Hrvati samo 2 mandata. Ipak, u Sabor su ušli i biskupi-virilisti, Hrvati Juraj Dobrila i Ivan Vitezić te Slovenac Bartol Legat ${ }^{86}$. Već na prvim zasjedanjima istarski preporodni svećenici predlagali su da hrvatski i slovenski jezik budu ravnopravni s talijanskim jezikom u Saboru i u uredima potičući time pitanje od središnje važnosti za preporodne pokrete na poluotoku. Tako su tu prvu etapu središnje faze hrvatske nacionalne integracije u Istri 1860-ih karakterizirali „pokretljiviji, organiziraniji i opsežniji rad pregalaca u širenju nacionalne svijesti ${ }^{\prime \prime 87}$. No pokušaji talijanizacije Istre nisu posustajali. Izglasavanjem Općinskog zakona u Pokrajinskom saboru (srpanj 1863.) bilo je predviđeno da se sve općine koje nisu imale uvjeta za samostalno upravljanje pripoje gospodarski i kulturno jačim općinama, a to su bile one talijanske. Na taj način ukinut je velik broj malih općina, većinski hrvatskih i slovenskih, te su okupljene oko talijanskih gradića kao općinskih središta, čime je bilo olakšano daljnje prodiranje talijanskog jezika i kulture u hrvatska i slovenska sela ${ }^{88}$.

\footnotetext{
81 Šetić 2005, 45id.

82

Bratulić, Vjekoslav, 1954. Pregled povijesti Istre, Rijeka: Otokar Keršovani, 30. Barbalić, Fran, 1954. Prvi istarski sabori (1861-1877.), RAD JAZU (1954), knj.300, Zagreb: JAZU; Šetić $2005,46$. Šetić 2005, 46-47.

Šetić 2005, 47.
} 
Uz to, djelovanje na širenju nacionalne svijesti u Istri kočila je i laicizacija škola koju je provela austrijska vlada $1869 .{ }^{89}$ Problem je bio u tome što su time prestale djelovati osnovne crkvene škole u kojima su učenici poučavani na hrvatskom i slovenskom jeziku. No ključno je bilo to što nove laičke hrvatske škole nisu istodobno bile otvarane, s obzirom na to da je rad osnovnih i srednjih škola tada ovisio o općinama koje su većinom bile pod upravom Talijana ${ }^{90}$. U procesu nacionalne asimilacije temeljni je čimbenik ekonomska zavisnost, što pokazuje primjer Bujštine, gdje se hrvatski seljak nalazio u kolonatskom odnosu prema talijanskim veleposjednicima. Međutim, u tome je golemu ulogu odigrala i škola. Talijanskom vladajućem sloju u Istri bilo je sasvim jasno kakva je uloga škole na materinskom jeziku, s obzirom na to da nikada nije dozvolio da se ni u Rijeci ni u Puli otvori čak ni osnovna pokrajinska škola ${ }^{91}$.

Drugu etapu središnje faze nacionalne integracije istarskih Hrvata obilježavali su događaji 1870. - 1882. - od pojave lista Naša sloga do smrti biskupa J. Dobrile $^{92}$. Našu slogu pokrenuo je 1870. biskup Dobrila, koji je uviđao potrebu snažnijeg buđenja nacionalne svijesti $u$ istarskih Hrvata radi otpora nedavno uvedenoj dualističkoj politici (od 1867.), kao i uznapredovaloj talijanizaciji Istre. List je odražavao nacionalne i političke koncepcije preporodnog pokreta na poluotoku, širio je nacionalnu svijest, vodio borbu za ravnopravnost Hrvata i Slovenaca s Talijanima, za suradnju južnoslavenskih naroda te za međusobno povezivanje Hrvata svih dijelova Istre i Kvarnerskih otoka ${ }^{93}$. Pomoću Naše sloge istarski je seljak dobio jasniji nacionalni i politički program u političkoj borbi protiv talijanske premoći, a za očuvanje i afirmaciju hrvatskih obilježja Istre kao dijela hrvatskog etničkog područja ${ }^{94}$.

U ovoj drugoj etapi središnje faze hrvatski preporodni pokret bliže surađuje sa slovenskim u otporu talijanizaciji Istre. Bliska suradnja Hrvata i Slovenaca u društvu Edinost dovela je u Istri do osnivanja zajedničke Hrvatsko-slovenske narodne stranke (1878. $)^{95}$. Neposredan povod tom povezivanju bilo je izbijanje velike Istočne krize (1875.-78.), kada se razmahala iredentistička agitacija iz Italije nudeći istarskim Talijanima program priključenja Istre Italiji. Upravo je pred

\footnotetext{
89 Milanović 1991, I, 314-316.

Šetić 2005, 47.

Peruško, Tone, 1969. Borba za osnovno školstvo - borba za nacionalni opstanak, u: Hrvatski narodni preporod u Dalmaciji i Istri: zbornik (Ravlić, Jakša, ur.), Zagreb: Matica hrvatska, 1969, 425-426.

Šetić 2005, 47.

Šepić 2004, 39.

Šetić 2005, 48.

Šetić 2015, 188.
} 
tom neposrednom prijetnjom narodni pokret istarskih Hrvata nastojao svoje političko djelovanje što tješnje povezati s onim primorskih Slovenaca, koji su bili ugroženi na isti način ${ }^{96}$.

U trećoj etapi središnje faze hrvatskog nacionalno-integracijskog procesa $\mathrm{u}$ Istri, glavna borba (1882. - 1907.) vodila se za područje zapadne Istre, gdje je narodni pokret nailazio na najžešći otpor Talijana i na najslabiju potporu hrvatskih seljaka ${ }^{97}$. S obzirom na to da Berlinski kongres (1878.) nije uzeo u razmatranje neke kompenzacije Italiji za austrijsku okupaciju Bosne i Hercegovine, Italija se - diplomatski izolirana i razljućena zbog francuske okupacije Tunisa - okrenula Njemačkoj i Austro-Ugarskoj te je s njima 1882. potpisala ugovor o Trojnom savezu. Talijanska liberalna stranka u Istri i dalje je računala na vladu Italije, premda je ova javno poricala da potpomaže iredentu, te se nastavilo djelovanje na širenju talijanstva na Istarskom poluotoku. Tako talijansko liberalno građanstvo osniva 1884. organizaciju Società politica istriana s programom širenja „talijanske narodnosti, civilizacije i kulture ${ }^{\mu 98}$. Sjedište tog društva smješteno je u Pazinu, kako bi se u središtu Istre stvorio centar talijanstva koji će suzbijati širenje $\mathrm{Hr}$ vatskog narodnog preporoda. U pravcu talijanizacije djeluje i društvo Pro patria (od 1886.). Taaffeova vlada zauzima neutralan stav; ona načelno priznaje ravnopravnost Hrvata i Slovenaca s Talijanima i u tom duhu donosi 1883. Zakon o ravnopravnosti pokrajinskih jezika na sudovima u Istri. No ona ne želi izazivati Kraljevinu Italiju, partnera $\mathrm{u}$ Trojnom savezu, pa u praksi tolerira dominaciju Talijanske liberalne stranke i njezinu politiku talijanizacije Istre. Taaffeova vlada ne želi dati povoda talijanskoj vladi da se žali na njezine postupke prema Talijanima u Habsburškoj Monarhiji ${ }^{99}$. No hrvatski narodni pokret unatoč tome jača u svom otporu talijanizaciji, čemu je pridonosio i opći gospodarski razvitak Istre koji je stvarao uvjete za nastanak hrvatskog i slovenskog građanskog sloja. Uz sustavan rad na narodnom prosvjećivanju, u Istri se razvija i široka mreža gospodarskih društava i štedionica koje su pridonosile oslobađanju seljaka od ovisnosti o talijanskom gradu ${ }^{100}$. Napokon, prilikom izbora 1886. Narodna stranka pobjeđuje u Općini Pazin, a 1887. i u Općini Buzet, što pokazuje da se narodni pokret uspio konačno učvrstiti u tim općinama središnje Istre. Tih godina Narodna stranka dobiva u svoje ruke gotove sve općine i na Kvarnerskim otocima i u Liburniji, a nakon pada Pazina i Buzeta u njezine ruke postupno prelaze go-

\footnotetext{
96 Šepić 2004, 40.

97 Šetić $2005,50$.

98 Šepić 2004, 69.

99 Šepić 2004, 69-70.

100 Šetić 2005, 50,
} 
tovo sve općine jugoistočne i srednje Istre ${ }^{101}$. U suprotstavljanju organiziranom nastojanju na širenju talijanskih škola u hrvatskim selima preko društva Lega Nazionale, koje je financirano iz Italije, Hrvati u Istri osnivaju 1893. „Družbu sv. Ćirila i Metoda za Istru" s ciljem prikupljanja sredstava za otvaranje hrvatskih pučkih škola na poluotoku ${ }^{102}$.

Talijani u odgovoru na hrvatsko nacionalno buđenje potpomažu tzv. Istrijanski pokret dalmatinskoga Hrvata Ivana Krstića. On je uživao potporu Talijanske liberalne stranke, te je preko svog lista Prava naša sloga (osnovanog 1896.) vodio kampanju protiv vodstva Hrvatsko-slovenske narodne stranke, ali je imao tek ograničen uspjeh $u$ istočnoj Istri ${ }^{103}$. Činilo se da je odlučna faza hrvatske nacionalne integracije na svom vrhuncu. Međutim, potkraj 19. i početkom 20. stoljeća, unatoč evidentnim uspjesima u svom nastojanju da se gospodarski osamostale, prosvjetno uzdignu i politički ustroje, istarski Hrvati i Slovenci još su uvijek bili u slabom položaju u odnosu na Talijane. Držeći u rukama veći dio veleposjeda, industrije, trgovine i obrta, Talijani su preko svoje najjače stranke upravljali autonomnim poslovima Istre. Nakon velikih uspjeha 1880-ih, činilo se kao da je pobjedonosno širenje narodnog pokreta bilo zaustavljeno ${ }^{104}$. Talijanska liberalna stranka djelovala je nepomirljivo, ohrabrena odlučnim stavom Italije koja se 1902. približava Francuskoj. Ona i dalje inzistira na priznavanju da je Istra talijanska pokrajina. No to nije moglo više ugroziti hrvatski narodni pokret $u$ Istri koji početkom 20. stoljeća postaje masovan, zahvaćajući gotovo sve društvene slojeve. U to doba reorganiziran je i rad Hrvatsko-slovenske narodne stranke, te su otada njezini političari više boravili na terenu, po selima, što je donijelo veliku pobjedu stranke nad Talijanima u izborima za bečko Carevinsko vijeće $(1907 .)^{105}$. Dva politički suprotstavljena bloka - talijanski te hrvatsko-slovenski - ostat će rigidno podijeljena i nepomirljiva sve do 1914. i kao takvi ući će u Veliki rat. O intenzitetu emocija prigodom izborne pobjede Hrvata i Slovenaca na izborima 1907. svjedoči pisanje Naše sloge: „Istra je uskrsnula! Propast tirana! Narod je pobijedio svoje tlačitelje..." ${ }^{\prime 106} S$ druge strane, jedan od prvaka Talijanske liberalne stranke, Lodovico Rizzi, objašnjavao je u doba politike „novog kursa”

\footnotetext{
101 Šepić 2004, 70.

102 Šetić 2005, 51.

103 Šepić 2004, 45

104 Šepić, Dragovan, 1969. Nacionalna borba u Istri i izbori za Carevinsko vijeće 1907., u: Hrvatski narodni preporod u Dalmaciji i Istri: zbornik (Ravlić, Jakša, ur.), Zagreb: Matica hrvatska, 1969, 403.

105 Šepić 1969; Šetić 2005, 51.

106 Trogrlić, Stipan, 1993. Istra između klerikalizma i liberalizma: (kraj 19. i početak 20. stoljeća), Društvena istraživanja, 4-5 (6-7), Zagreb, 662.
} 
zašto su Talijani protiv sporazuma s Hrvatima i Slovencima, koje naziva skupno "Slaveni“: „Mi smo brojčano slabiji... Slaveni pak ne samo da su u našim krajevima brojčano jači nego uživaju i pomoć milijuna drugih Slavena Austrije. Kada se u Istri i Goriškoj poboljšaju njihove kulturne i ekonomske prilike, mi smo osuđeni da budemo od njih svladani. Stoga je prirodno što se svim snagama borimo kako bi sačuvali naše pozicije... Ne poričem da naša politika često neće biti pravedna, ali mi znamo kakva bi nas sudbina čekala kad bi sami omogućili ubrzanje onog procesa koji Slaveni smatraju u bližoj ili daljoj budućnosti neminovnim. Zbog toga postignuće sporazuma predstavlja gotovo nepremostive teškoće. Primjer nam je Dalmacija ${ }^{\iota 107}$

Može se zaključiti da je razdoblje ustrajne borbe triju naroda Istre - Hrvata, Slovenaca i Talijana - za pravo na vlastitu samobitnost i samoodređenje, uključivalo objektivne čimbenike, kao i one emocionalno-psihološke i makijavelističke naravi. Time je posijano sjeme zla i za buduća desetljeća u 20. stoljeću. No presudan doprinos tragičnim istarskim sukobljavanjima u 20. stoljeću dat će manipulativna austrijska politika u drugoj polovici 19. stoljeća.

\section{Austrijska politika u drugoj polovici 19. stoljeća kao uzrok istarskih sukobljavanja}

Na društvene i političke odnose u Istri u drugoj polovici 19. stoljeća posebno su negativno djelovale dvije politike koje su provodile austrijske vlasti: ona koja je dosljedno proizlazila iz dualističkog ustrojstva države te politika „podijeli pa vladaj" (divide et impera).

Posljedice teškog poraza Austrije u ratu 1866. protiv Pruske bile su uistinu dramatične za nju. Prvo, Austrija je bila definitivno izbačena iz njemačkih poslova, a Bismarck će na temelju tzv. malonjemačke koncepcije pristupiti procesu nacionalnog ujedinjenja Njemačke pod vodstvom Pruske - ali bez Austrije. Drugo, Austrija je bila prisiljena promijeniti svoj vanjskopolitički pravac prema jugoistoku Europe, te će uskoro Balkan postati sve važniji objekt suparništva Austrije i Rusije. Treće, uslijed neizvjesnosti austrijskih vladajućih krugova oko daljnjih planova Pruske, vjerojatno pojačane sjećanjem na politiku Friedricha Velikog prema Mariji Tereziji u 18. stoljeću, nametnuo se imperativan zahtjev da se Habsburška Monarhija konsolidira iznutra i da učvrsti internu koheziju države, što bi bio temeljni preduvjet njezine obrambene sposobnosti ili vanjskoga nastupa kao velike sile. Bio je to bitan razlog, uz Bismarckov nagovor Bečkog dvora, da se ovaj odlučio na uspostavu ravnoteže unutar Monarhije s drugim najjačim čimbenikom, Ugarskom, a na štetu slavenskih naroda pa tako i hrvatskoga naroda.

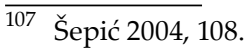


Već od proljeća 1866. bilo je sve jasnije da će se državna kriza Carevine razriješiti podjelom vlasti između Nijemaca i Mađara. Probuđeni nacionalni pokreti u višenacionalnoj Habsburškoj Monarhiji i jačanje građanske koncepcije društva žurno su nametali pitanje preustroja države. Austrijanci i Mađari odbacili su i centralizam, kao potrošen i zastario oblik vladavine, te federalizam - njima trenutačno neodgovarajući sustav odnosa. Oni su se opredijelili za dualizam, kako bi svojim nametnutim dvovlašćem uspostavili potpunu dominaciju nad slavenskim narodima unutar Monarhije ${ }^{108}$. Tako će kancelar Belcredi, koji se zalagao za federalistički preustroj Monarhije, biti zamijenjen zagovornikom dualizma, saksonskim grofom Beustom, te 21. prosinca 1867. dolazi i formalno do Austrougarske nagodbe ${ }^{109}$. Austrijanci i Mađari međusobno su podijelili državnu vlast i teritorij stvorivši složenu državu dualističkog tipa. Zajednički su im bili vladar, obrana i vanjska politika te financije, a teritorij države podijeljen je na austrijski (cislajtanski) i ugarski (translajtanski) dio. Ta podjela Carevine, uz osiguranje hegemonije vladajućih snaga Nijemaca i Mađara u njoj, značila je i dijeljenje slavenske većine, tamo gdje je ova bila prijeteća za austrijske ili mađarske interese. Dio južnih Slavena dospio je pod Austriju, dok je drugi dio postavljen u položaj da traži izlaz u nagodbi s Ugarskom, što se odnosilo na Hrvate. Navodno je austrijski kancelar Beust rekao ugarskom premijeru Andrassyju: „Čuvajte vi svoje horde, mi ćemo već svoje čuvati." ${ }^{\prime \prime 10}$ Ubrzo će biti sklopljena i Hrvatsko-ugarska nagodba (1868.), koja je okovala hrvatsku politiku za sljedećih 50 godina. Ona će utjecati na cjelokupni javni život Hrvatske, s time da će se najteže osjećati na ekonomskom području gdje će Hrvatska postati potpuno ovisna od Ugarske ${ }^{111}$. Podjela države između vladajućih austrijskih i mađarskih krugova bila je gotovo fatalna za proces hrvatske nacionalne integracije, bitno ga otežavajući i ograničavajući. Naime, hrvatske zemlje našle su se sada, premda i do tada upravno razdvojene, u dvije države unutar dualističke strukture ${ }^{112}$. Istra i Dalmacija pripale su austrijskom dijelu, a banska Hrvatska (Hrvatska i Slavonija) ugarskom dijelu Monarhije. Vojnom krajinom upravljao je neposredno Beč. Istarski i dalmatinski Hrvati doživjeli su takav dualistički ustroj i politiku koja je iz njega proizlazila, kao odgodu rješenja hrvatskog pitanja na neodređeno vrijeme. Naime, takvom podjelom austrijski i mađarski politički vrhovi uspostavili su ravnotežu i činilo

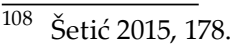

Šišić, Ferdo, 2004. Povijest Hrvata: pregled povijesti hrvatskoga naroda, II, Split: Marjan tisak, 462-463.

110 Šarinić, Josip, 1972. Nagodbena Hrvatska: postanak i osnove ustavne organizacije, Zagreb: Nakladni zavod Matice hrvatske, 175.

111 Horvat, Josip, 1990. Politička povijest Hrvatske; I-II, Zagreb: August Cesarec, I, 193.

112 Šetić 2015, 179.
} 
se da ni jedni ni drugi ni u kojem slučaju ne bi dozvolili da se ta novostvorena ravnoteža unutar države poremeti. Stoga je postalo sasvim jasno da, dok takav dualizam istrajava, ujedinjenje hrvatskih zemalja nije moguće, jer bi ono poremetilo austro-ugarsku teritorijalnu ravnotežu ${ }^{113}$. Za razliku od Banske Hrvatske, čiji je državnopravni položaj bio ustrojen Hrvatsko-ugarskom nagodbom (1868.), Istra i Dalmacija postale su, svaka sa svojom zasebnom pokrajinskom upravom i ograničenom samoupravom, bez bilo kakve nagodbe s Austrijom - sastavnim dijelom austrijskog dijela Carevine, i to s ustavnopravnim položajem dobivenim još Veljačkim patentom $1861^{114}$. Iz tako ustrojene države proizlazila je i odgovarajuća dualistička politika. Kao jedna od temeljnih zadaća dualističkih vlada u Banovini i Dalmaciji bila je ta da spriječe jačanje snaga koje teže ujedinjenju hrvatskih zemalja, pa su strogo pazile da onemoguće povezivanje političkih akcija $\mathrm{u}$ obje pokrajine ${ }^{115}$. Tako je podizanje dualističkog zida između hrvatskih zemalja destruktivno djelovalo na proces hrvatske nacionalne integracije i u Istri.

Dualistički sustav dodatno je bio zacementiran nakon ujedinjenja Njemačke. Bismarck će čvrsto stati iza Dvojne Monarhije i podržavati njezinu politiku; štoviše, ući će s njom u Dvojni savez (1879.), kojemu će pristupiti i Italija u Trojnom savezu (1882.). Cilj njemačkih sila bio je prodor na Istok (Drang nach Osten) prema umirućem Otomanskom Carstvu, unutar kojega su Britanija i Francuska već zauzele važne ekonomske i financijske pozicije. No da bi takav pohod Njemačke i Austro-Ugarske prema Istoku bio moguć, Dvojna Monarhija morala je nadalje ojačati svoju unutarnju koheziju i ustrojstvo, što je značilo da od sada i Njemačka podržava dualističku politiku. Što je Njemačko Carstvo bilo moćnije, to je bio jači vanjski oslonac konzervativnim snagama unutar Austro-Ugarske koje su bile nesklone idejama Slavena, pa onda i Hrvata, o nacionalnoj emancipaciji. Naime, u slučaju pobjede protudualističkih snaga, koje su uglavnom bile usmjerene i protunjemački, bitno bi se promijenila i unutarnja i vanjska politika Austro-Ugarske s brojnim i nepredvidivim implikacijama ${ }^{116}$.

Kako se to ne bi dogodilo, austrijske vlasti održavale su dominaciju nad potlačenim narodima suptilnom politikom „podijeli pa vladaj“. U Istri će ona stvarati i dodatno produbljivati nerazumijevanja, opreke i postojeće sukobe između Talijana, s jedne, te Hrvata i Slovenaca, s druge strane, sijući klice zla za budućnost. Pritisnute centrifugalnim silama i tendencijama iznutra i izvana, austrijske vlasti provodile su u Istri tri slične varijante politike „podijeli pa vladaj”

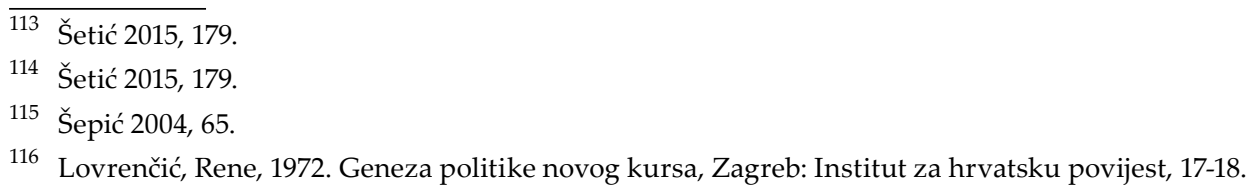


u ovisnosti o promjenama okolnosti te različitim shvaćanjima uključenih aktera. U pokušaju potpunijeg razumijevanja zbivanja navest ćemo sva tri pristupa.

Prvo, klasična tehnika „podijeli pa vladaj“ s davanjem naizmjeničnih prednosti uključenim stranama. Habsburgovci su tradicionalno bili poznati po vještom vođenju politike divide et impera kako bi unutar svog raznolikog imperija prevenirali stvaranje ujedinjene oporbe potlačenih naroda protiv središnje vlasti. U Istri je njihova formula bila održavanje tenzije između Talijana, s jedne, te Hrvata i Slovenaca, s druge strane, uz davanje naizmjeničnih prednosti stranama u ovisnosti o promjenama međunarodnih okolnosti. Austrijska vlada načelno je vodila politiku germanizacije, a tamo gdje ponjemčivanje nije imalo nikakva temelja bila je tolerantna, pa čak i naklonjena talijanskoj dominaciji; to je bilo osobito primjetno u Istri ${ }^{117}$. Isprva se Talijane nastojalo povlašćivanjem odobrovoljiti da odustanu od iredentističke politike prema Austriji, ali i spriječiti stalne žalbe Italije o tome kako austrijske vlasti nepovoljno tretiraju talijansku manjinu. Car Franjo Josip I. iz političkih je razloga uveo prema Talijanima već 1875. „,blagu i dobrohotnu politiku koje se kasnije uvijek držao" te je austrijska vlada, pisao je Milanović, imala sve do konca 19. stoljeća u Istri pred očima samo Talijane $e^{118}$.

Međutim, talijanski pritisak proizvodi reakciju Hrvata i Slovenaca, te od 1870-ih jačaju njihovi nacionalno-preporodni pokreti. Sada su austrijske vlasti prinuđene na manipulativnu razdiobu u duhu politike "podijeli pa vladaj“. Tamo gdje je, kaže Vivante, slavensko stanovništvo „prejako prodiralo“, kao npr. u Kranjskoj, germanizacija će djelovati kao značajna protuteža, a tamo gdje su Talijani isključivo dominirali, a ponjemčivanje nije uspjelo - protuteža su bili Slaveni, kao npr. u Julijskoj krajini. „Složenost tih akcija i reakcija proizvodi onoliko ravnovjesja koliko je nužno centralizmu za svladavanje raznih strujanja; igra što, dakako, postaje sve težom i opasnijom. ${ }^{\prime 119}$ Iza postupaka austrijskih vlasti može se nazrijeti promišljena i sustavna politika "podijeli pa vladaj” s davanjem naizmjeničnih prednosti uključenim akterima. Austro-Ugarska je provodila rimsku politiku divide et impera favorizirajući sad jednog, sad drugog partnera te je, suprotstavljajući jedne drugima, mogla mirno vladati ${ }^{120}$. Namjerno inducirani nacionalni sukobi u Istri išli su nesumnjivo na ruku austrijskoj politici. Ona je, s jedne strane, favorizirala germanizaciju, dok je, s druge, za-

117 Vivante 2002, 145.

118 Milanović, Božo, 1992. Istra u 20. stoljeću: zabilješke i razmišljanja o proživljenom vremenu; I-II, Pazin: Istarsko književno društvo „Juraj Dobrila“, I, 9-10.

119 Vivante 2002, 145.

120 Buršić, Herman, 2011. Od ropstva do slobode: Istra 1918.-1945.: male bilješke o velikom putu, Pula: Histria Croatica C.A.S.H., 44. 
strašivala „iredentizam i panslavizam dajući koncesije sad jednim sad drugima, prema poslovici 'podijeli pa vladaj', i s uspjehom vladala situacijom u Istri sve do kraja svoje vladavine.“121

Ova politička tehnika bila je konstanta austrijske politike u Istri, ali su spominjane još neke, ovisno o kutu gledanja uključenih strana.

Drugo, austrijske vlasti izrazito povlašćuju Hrvate i Slovence u Istri, što je bila omiljena teza talijanskih nacionalista. Osim davanja naizmjeničnih prednosti, tehnika "podijeli pa vladaj“ može obuhvaćati i izrazito favoriziranje samo jedne strane protiv druge. Primjetno je bilo to da je Austrija, kada bi god osjetila da je talijansko građanstvo ugrožava, tražila mogućnosti da protiv njega usmjeri snage hrvatskih i slovenskih seljaka ${ }^{122}$. No talijanska promidžba posebno je inzistirala na navodnom izrazitom favoriziranju Hrvata i Slovenaca u Istri od strane austrijskih vlasti kako bi se kontrolirali Talijani. Tako je za Hrvatski narodni preporod $\mathrm{u}$ Istri talijanska historiografija uglavnom tvrdila da je taj pokret manje ili više tvorba Austrije ili da su gotove ideje prenošene iz Banske Hrvatske ${ }^{123}$. Ona je tvrdila da je Austriji navodno bilo u interesu da jača položaj Hrvata i Slovenaca u cilju „suzbijanja talijanskoga nacionalnog pokreta“ u Istri i njegove emanacije talijanskoga iredentizma, koji je dobio novi polet i uzeo veći zamah nakon ujedinjenja Italije, a iz Hrvatske da su pritjecala u Istru materijalna sredstva i moralno-politička pomoć radi izazivanja sukoba s Talijanima ${ }^{124}$.

Niz talijanskih povjesničara tvrdio je da je Austrija nakon 1866. u Istri konstruirala, naprosto stvorila, hrvatsko nacionalno pitanje samo zato da bi spriječila konačnu pobjedu talijanskog elementa ${ }^{125}$. Austrija je navodno povlašćivala pokrete Hrvata i Slovenaca u Istri, jer se našla između dvije ugroze: između slavenske, koja je prijetila s istoka i činila se ipak dalekom; i talijanske, koja je prijetila neposrednom pobunom i iredentizmom. U to doba slaba Hrvatska, teško pritisnuta borbom protiv mađarizacije, i još od Europe veoma udaljena Rusija, nisu bili dovoljno poticajni akteri za izbijanje ustanka Hrvata i Slovenaca u Istri. Međutim, prijeteće promjene lojalnosti i spletke Kraljevine Italije u međunarodnoj politici itekako su mogle imati, držali su austrijski političari, neposrednijeg utjecaja na lojalnost talijanskog elementa u Istri. Talijanski pisci čvrsto su se

\footnotetext{
121 Darovec, Darko, 1997. Pregled istarske povijesti, Pula: C.A.S.H, 74.

122 Črnja, Zvane, 1976. U Istri tisuću osamsto četrdeset osme, Istra, 8, 34

123 Strčić, Petar, 1969. Počeci organiziranog političkog pokreta Hrvata u Istri u XIX stoljeću, Jugoslavenski istorijski časopis, 4, Beograd, 65.

124 Bratulić 1969. 289.

125 Lukić, Berislav, 1956. Neka mišljenja u talijanskoj građanskoj historiografiji o karakteru nacionalnog pokreta u Istri, Jadranski zbornik, 1, 157.
} 
uhvatili tog motiva o povlašćivanju Hrvata i Slovenaca. De Franceschi je tvrdio da „slavensku agitaciju u Istri u cijelosti vode kranjski i liburnijski popovi, posebno oni koji potječu iz Kastva i s otoka Krka... agitacija je sada življa nego ikada, jer je dovoljno ne obuzdavaju javne vlasti, posebno u naše vrijeme kada je središnja vlada nepostojana u svojim odlukama pred zahtjevima svih Slavena u Carstvu, koji žele nadjačati dosadašnju nadmoć Nijemaca da im otmu žezlo hegemonije ${ }^{\prime \prime 26}$. On je dakle uvjeren da je nacionalni pokret i Hrvata i Slovenaca u Istri djelo „stranoga klera“ ili da je „umjetna tvorevina austrijske vlade ${ }^{\prime \prime 27}$.

Treće, austrijske vlasti izrazito povlašćuju Talijane u Istri. Ovo je bio uobičajen pogled Hrvata i Slovenaca na situaciju u Istri u drugoj polovici 19. stoljeća. Taffeova vlada formalno zauzima neutralan stav u pogledu nacionalne borbe Talijana s Hrvatima i Slovencima u Istri. Ona načelno priznaje ravnopravnost Hrvata i Slovenaca s Talijanima i u tom duhu donosi 1883. Zakon o ravnopravnosti pokrajinskih jezika na sudovima u Istri, ali je u praksi tolerirala premoć Talijanske liberalne stranke i njezine politike talijanizacije poluotoka. Naime, Taaffeova vlada nije željela dati povoda vladi Italije da se žali na njezine postupke prema Talijanima unutar Habsburške Monarhije ${ }^{128}$. Jedno od objašnjenja za to austrijsko protežiranje istarskih Talijana upućuje na potrebu austrijskih vlasti da guše buđenje svijesti u Hrvata i Slovenaca uslijed straha od penetracije Rusije i širenja panslavizma. Prema toj eksplanaciji, zapravo su glavni problem za Austriju u Istri bili Hrvati i Slovenci koji su činili većinu stanovništva, a oni su „samo ogranak južnoslavenskih naroda koji su za kompaktnost i sigurnost Austrije predstavljali veću globalnu opasnost od države koja se rađala na Apeninskom poluotoku“/129. S obzirom na to da je nova talijanska država aspirirala na habsburške teritorije, austrijska vlast morala je povlašćivati Talijane. Pri tome Talijani nisu smjeli dobiti sve, jer bi se u tom slučaju ravnoteža previše nagnula u njihovu korist, što austrijskim vlastima nije bilo u interesu.

Tako je zamijećeno da je $u$ pojedinim razdobljima, kao npr. nakon raspada Trocarskog saveza u bugarskoj krizi i uvijek kada je Rusija prodirala na Balkan, Austro-Ugarska djelovala protuslavenski te je izrazito favorizirala talijansku manjinu. Premda su austrijske vlasti bile svjesne prikrivene iredente Talijana i nakon 1882., u nekim razdobljima puno većom prijetnjom činila joj se pobuna slavenske većine koja bi Monarhiju mogla ugroziti u samom njezinu srcu. Stoga je austrougarska vlada potiskivala buđenje nacionalne svijesti u Istri kod Hrvata i Slovenaca

\footnotetext{
126 De Franceschi 1989, 170-171.

127 Lukić 1956, 158.

128 Lukić 1956, 69-70.

129 Črnja 1976, 34.
} 
podržavajući Talijane kao manje opasne ${ }^{130}$. Tako je Talijanska liberalna stranka počela surađivati s austrijskim vlastima te dobiva otvorenu mogućnost da u Istri, Trstu, Gorici i drugdje sustavno provodi aktivnosti talijanizacije, uz istodobno onemogućavanje razvitka nacionalne svijesti u Hrvata i Slovenaca ${ }^{131}$. Posljedice takve austrijske politike vidljive su $\mathrm{u}$ činjenici da su Talijani počeli percipirati istarske Hrvate i Slovence kao istinske neprijatelje.

\section{Zaključak}

Treba li u objašnjavanju uzroka istarskih sukobljavanja u dugom 19. stoljeću preferirati unutarnje ili vanjske kauzalne čimbenike? Drugim riječima, jesu li procesi nacionalne integracije triju naroda unutar Istarskog poluotoka važniji uzročni čimbenik od dinamičnih procesa europske ravnoteže snaga i one regionalne na Jadranu između Italije i Austrije? Odgovor u ovom radu glasio bi da su relevantni i unutarnji i vanjski uzročni čimbenici u eksplaniranju 19-stoljetnih nacionalnih sukobljavanja u Istri, pri čemu se posebno ukazuje na važnost vanjskih čimbenika koji se često zanemaruju ili tek površno razmatraju. No ako želimo doći do cjelovitijeg odgovora, svakako trebamo analizirati unutarnje i vanjske kauzalne čimbenike nastojeći što potpunije zahvatiti taj dramatični povijesni i društveni fenomen.

Od unutarnjih uzročnih čimbenika primarno valja istaknuti važnost triju gotovo istodobnih preporodnih i nacionalnointegracijskih procesa u Istri u 19. stoljeću, između Talijana, Hrvata i Slovenaca. Talijanski Risorgimento u Istri bio je odraz istovjetnog procesa u Apeninima, nakon nacionalnog ujedinjenja Italije (1861.), koji je započeo nešto prije nego preporodni nacionalnointegracijski procesi Hrvata i Slovenaca u Istri. Premda su preporodni pokreti istarskih Hrvata i Slovenaca također bili odraz istovjetnih pokreta u njihovim maticama, oni su dobrim dijelom bili i reakcija na agresivnost talijanskoga nacionalizma i iredentizma koji su se u Istru prelijevali s Apenina. Štoviše, hrvatski i slovenski nacionalni pokreti ubrzo su bili upućeni na suradnju kako bi se zajednički oduprli pritisku talijanizacije, osobito od vremena proglašenja talijanske moderne države Kraljevine Italije 1861. godine.

Drugi fundamentalni unutarnji uzročni čimbenik sukobljavanja nesumnjivo je bila austrijska politika „podijeli pa vladaj“, koja je nastojala dugoročno očuvati dualističko ustrojstvo države antagoniziranjem Talijana u Istri s Hrvatima i Slovencima. S obzirom na to da je ta politika dolazila iz Beča, ona je samo uvjetno unutarnji čimbenik.

\footnotetext{
130 Bratulić 1954, 36

131 Šepić 2004, 228.
} 
Od vanjskih kauzalnih čimbenika istarskih sukobljavanja u dugom 19. stoljeću prvenstveno ističemo hirovite dinamizme međunarodne strukture, osobito europske ravnoteže snaga, koji su nosili povremeno neizravne posljedice nižim razinama sustava. Tako je privremena blagonaklonost europskih sila prema Sardiniji, odnosno omogućavanje francuskom caru Napoleonu III. da povede s Talijanima rat protiv Austrije (1859.), završila ujedinjenjem Italije 1861. godine. No problem je sada bio u tome što su talijanske elite postale uvjerene u iluziju o vlastitoj svemoći te su težile daljnjem osvajanju habsburških teritorija, među kojima su bile Istra i Dalmacija. Tako će do 1870-ih nezakočeni talijanski iredentizam preplavljivati Istru s neskrivenom ambicijom da pripoji poluotok Kraljevini Italiji. Zatim će ujedinjenje Njemačke pod Bismarckom (1871.), njegov savez s Austrijom (1879.) i priključenje Italije u Trojni savez (1882.) zakočiti otvoreno prelijevanje talijanskog iredentizma u habsburške zemlje, premda će se on u njih, pa i u Istru, prelijevati tajnim kanalima i preko različitih društava. Nakon poraza talijanske kolonijalne vojske kod Adue (1896.), talijanski imperijalizam ponovo se okreće prema habsburškim i osmanskim zemljama.

Drugi ključan vanjski čimbenik bio je poraz Austrije u ratu protiv Pruske (1866.), kada je izbačena iz njemačkoga prostora, premjestila težište svoje politike prema jugoistoku i bila prisiljena na sklapanje nagodbe s Mađarima 1867. godine. Posljedica je bila dualistička politika koja je dugoročno petrificirala odvojenost hrvatskih zemalja teško ometajući proces hrvatske nacionalne integracije u Istri. Zatim će pohod Centralnih sila prema istoku i jugoistoku Europe dodatno potencirati dualističku politiku Austro-Ugarske sprječavajući daljnji proces hrvatske nacionalne integracije. No ta je politika, s druge strane, pojačavala odlučnost hrvatskih preporoditelja u Istri, pa nije bilo slučajno to što je biskup Dobrila upravo 1870. godine, nedugo nakon Austro-ugarske nagodbe, pokrenuo list Naša sloga. Uslijedila su duga desetljeća borbe Hrvata i Slovenaca u Istri protiv talijanizacije s promjenjivim uspjehom.

Treći važan čimbenik bio je pristupanje Italije Trojnom savezu (1882.), kada se ona okreće kolonijalnim osvajanjima, ali uvijek s jednim okom na „neoslobođenim zemljama" u Austro-Ugarskoj Monarhiji. Austrijske vlasti dozvoljavaju dominaciju Talijanima u Istri, premda će politika „podijeli pa vladaj“ ostati glavno oružje austrijske hegemonije sijući zlo na poluotoku.

Četvrto, za daljnje zaoštravanje odnosa u Istri izvjesnu uzročnu važnost ima i težak poraz talijanskih kolonijalnih ambicija kod Adue (1896.) od etiopskih domorodaca, kada se Kraljevina Italija približava Francuskoj (1900., 1902.) i okreće svoj imperijalistički interes ponovo prema habsburškim teritorijima. Jasna manifestacija toga zaokreta bit će za Istru sudbonosan tajni Londonski ugovor 1915. godine i buduća okupacija toga područja po završetku Prvoga svjetskoga rata. 


\section{IZVORI I LITERATURA}

\section{Literatura}

Ashbrook, John E., 2008. Buying and Selling the Istrian Goat: Istrian Regionalism, Croatian Nationalism and EU Enlargement, Bruxelles: P.I.E. Peter Lang.

Barbalić, Fran, 1954. Prvi istarski sabori (1861-1877.), RAD JAZU, knj. 300, Zagreb: JAZU, 281-429.

Bertoša, Miroslav, 1977. Carlo Combi i njegovi pogledi na povijest Istre i etnički sastav njezina pučanstva, Pazinski memorijal - Katedra Čakavskog sabora u Pazinu, knj.7, Pazin, 179-201.

Bertoša, Miroslav, 1985. Etos i etnos zavičaja, Pula (etc): Čakavski sabor (etc), 151-176.

Bertoša, Miroslav, 2012. "Sve služi povijesti“ a povijest - politici i patriji. Skica za portret Tomasa Lucijanija (1818-1894.), političara, proučavatelja starina, arhivista, javnoga i tajnoga djelatnika, u: Polić, Orbanić (ur.), 2012., 353-369.

Bratulić, Vjekoslav, 1954. Pregled povijesti Istre, Rijeka: Otokar Keršovani.

Bratulić, Vjekoslav, 1969. Političke stranke u Istri za vrijeme Narodnog preporoda, u: Ravlić (ur.), 1969., 289-334.

Budak, Neven (ur.), 2011. Istarski sabor = La dieta istriana, Poreč: Zavičajni muzej Poreštine: Humaniora.

Buršić, Herman, 1978. Borba naroda Istre za svoje oslobođenje i sjedinjenje s maticom zemljom, Pomorski zbornik, knj. 16, 13-28.

Buršić, Herman, 2011. Od ropstva do slobode: Istra 1918-1945.: male bilješke o velikom putu, Pula: Histria Croatica C.A.S.H.

Cetnarowicz, Antoni, 2014. Narodni preporod u Istri (1860-1907.), Zagreb: Srednja Europa.

Chabod, Federico, 1978. Savremena Italija (1918-1948), Beograd: Nolit.

Combi, Carlo, 1867. Appello degli Istriani all' Italia. Padova, u: Ashbrook, 2008.

Combi, Carlo, 1890. Porta orientale. Strenina Istriana per gli'anni 1857-58-59 con la prefazione e note di Paolo Tedeschi. Capodistri, u: Cetnarowicz, 2014.

Črnja, Zvane, 1976. U Istri tisuću osamsto četrdeset osme, Istra, 8, Pula, 28-39.

Darovec, Darko, 1997. Pregled istarske povijesti, Pula: C.A.S.H.

Debidour, Antonin, 1933. Diplomatska istorija Evrope: od otvaranja Bečkog kongresa do zaključenja Berlinskog (1814-1878), I-II, Beograd: Geca Kon.

De Franceschi, Carlo, 1926. Memorie autobiografiche: con prefazione, note e appendici a cura del figlio Camillo. Trieste: Tipografia del Lloyd triestino, u: Lukić, 1956.

De Franceschi, Carlo, 1989. Uspomene, Pula (etc.): Čakavski sabor (etc.).

Dukovski, Darko, 2004. Istra: kratka povijest dugog trajanja: od proih naseobina do danas, Pula: Istarski ogranak DHK. 
Greenfeld, Liah, 1992. Nationalism: Five Roads to modernity, Cambridge, Mass, London: Harvard University Press, 1992.

Gross, Mirjana (ur.) 1981.: Društveni razvoj u Hrvatsko: (od 16. stoljeća do početka 20. stoljeća), Zagreb: Sveučilišna naklada Liber.

Gross, Mirjana, 1981. O integraciji hrvatske nacije, u: Gross (ur.), 1981., 175-190.

Gruber, Dane, 1924. Povijest Istre, Jastrebarsko: Braća hrvatskog zmaja, sv. 36.

Hayes, Carlton J.H., 1924-5. A Political and Social History of Modern Europe, I-II, New York: The Macmillan Company.

Holjevac, Željko (ur.), 2012. 1918. u hrvatskoj povijesti: zbornik, Zagreb: Matica hrvatska Horvat, Josip, 1990. Politička povijest Hrvatske, I-II, Zagreb: August Cesarec.

Hroch, Miroslav, 1979. Oblikovanje modernih nacija i nacionalni pokreti 19. stoljeća, Časopis za suvremenu povijest, 1, Zagreb, 23-40.

Hroch, Miroslav, 2006. Društveni preduvjeti nacionalnih preporoda u Europi: komparativna analiza društvenog sastava patriotskih grupa malih europskih nacija, Zagreb: Srednja Europa.

Kardum, Livia, 2000. Europska diplomacija i Proi svjetski rat, Zagreb: FPZ.

Lovrenčić, Rene, 1972. Geneza politike novog kursa, Zagreb: Institut za hrvatsku povijest.

Lukić, Berislav, 1956. Neka mišljenja u talijanskoj građanskoj historiografiji o karakteru nacionalnog pokreta u Istri, Jadranski zbornik, 1, 157-164.

Mack Smith, Denis, 1997. Modern Italy: A Political History, Ann Arbor: The Univ. of Michigan Press.

Manin Marino (ur.) 2001. Talijanska uprava na hrvatskom prostoru i egzodus Hrvata (1918.-1943.): zbornik radova, Zagreb: Hrvatski institut za povijest: Društvo Egzodus istarskih Hrvata.

Marjanović, Milan, 1960. Londonski ugovor iz godine 1915.: prilog povijesti borbe za Jadran 1914.-1917., Zagreb: JAZU.

Milanović, Božo, 1967. Hrvatski narodni preporod u Istri, I-II, Pazin: Istarsko književno društvo sv. Ćirila i Metoda.

Milanović, Božo, 1969. Biskup Dobrila i njegovo doba (1861-1882.), u: Ravlić (ur.), 1969., 351-402.

Milanović, Božo, 1991. Hrvatski narodni preporod u Istri, knj. I, 2. izd., Pazin: Istarsko književno društvo „Juraj Dobrila“.

Milanović, Božo, 1992. Istra u 20. stoljeću: zabilješke i razmišljanja o proživljenom vremenu, I-II, Pazin: Istarsko književno društvo „Juraj Dobrila“.

Mirković, Mijo, 1962. O sadržaju i smislu narodnog preporoda u Istri (1861-1914.), Jadranski zbornik, 5, Rijeka, Pula.

Mirković, Mijo, 1969. O smislu i sadržaju narodnog preporoda u Istri, u: Ravlić (ur.), 1969., 283-287. 
Novak, Bogdan, 1970. Trieste 1941-1954: The Ethnic, Political and Ideological Struggle, Chicago, London: The Univ. of Chicago Press.

Perić, Ivo, 2002. Hrvatska državotvorna misao u 19. i 20. stoljeću, Zagreb: Dom i svijet.

Peruško, Tone, 1969. Borba za osnovno školstvo - borba za nacionalni opstanak, u: Ravlić (ur.), 1969.

Polić, Maja, Orbanić, Elvis (ur.), 2012. Zbornik u čast Petru Strčiću, Rijeka: Povijesno društvo Rijeka, 353-369.

Poropat, Elena, 2011. Povijest Istarskog sabora kao političkog tijela, u: Budak (ur.), 2011. Potemkin, Vladimir P. (ur.) 1951. Historija diplomacije, I-III, Zagreb: Matica hrvatska, Procacci, Giuliano, 1996. Povijest Talijana, Zagreb: Barbat.

Quarantotti, Giovanni, 1938. Storia della Deta del Nessuno“. Parenzo, u: Milanović, 1969. Ravlić, Jakša (ur.) 1969. Hrvatski narodni preporod u Dalmaciji i Istri: zbornik, Zagreb: Matica hrvatska.

Rojnić, Matko, 1949. Nacionalno pitanje u Istri 1848-1849., Historijski zbornik, 2, Zagreb, 77-114.

Spinčić, Vjekoslav, 1924. Narodni preporod u Istri, u: Gruber, 1924.

Stančić, Nikša, 2002. Hrvatska nacija i nacionalizam u 19. i 20. stoljeću, Zagreb: Barbat, Strčić, Petar, 1969. Počeci organiziranog političkog pokreta Hrvata u Istri u XIX stoljeću, Jugoslovenski istorijski časopis, 4, Beograd, 95-99.

Strčić, Petar, 1991. Prilog poznavanju iredentističkih djelatnosti Carla Combija 50-tih i 60-tih godina XIX stoljeća, Annales, 1, 155-160.

Strčić, Petar, 2001. Egzodus Hrvata iz Istre i drugih hrvatskih krajeva između 1918. i 1958. godine kao politička, nacionalna i gospodarska pojava, u: Manin (ur.), 2001., 19-60.

Szabo, Agneza, Labus, Alan, 2012. Hrvatska povijest: odabrane teme, Zaprešić: Visoka škola za poslovanje i upravljanje s pravom javnosti „Baltazar Adam Krčelić“

Šarinić, Josip, 1972. Nagodbena Hrvatska: postanak i osnove ustavne organizacije, Zagreb: Nakladni zavod Matice hrvatske.

Šepić, Dragovan, 1969. Nacionalna borba u Istri i izbori za Carevinsko vijeće 1907. u: Ravlić (ur.), 1969., 403-422.

Šepić, Dragovan, 1974. Transformacije iredentizma, Istra, 6, Pula, 9-17.

Šepić, Dragovan, 1975.(a) Jadransko pitanje od 1915. do 1954., Istra, 1-2, Pula, 17-36.

Šepić, Dragovan, 1975.(b) Talijanski iredentizam na Jadranu. Konstante i transformacije, Časopis za suvremenu povijest, 1(17), Zagreb, 5-32.

Šepić, Dragovan, 1976. Istra u imperijalističkom programu Italije (do Londonskog ugovora 1915.), Pazinski memorijal, 5, 137-143.

Šepić, Dragovan, 1978. Talijanski iredentizam i istočna kriza 1875-1878., Istra, 5-6, 102-115. 
Šepić, Dragovan, 1981. O procesu integracije hrvatske nacije u Istri, u: Gross (ur.), 1981., 251-281.

Šepić, Dragovan, 2004. Hrvatski pokret u Istri XIX. i na početku XX. stoljeća, Buzet: Reprezent, Zagreb: HAZU.

Šetić, Nevio, 1993. O procesu nastanka suvremene hrvatske nacije u Istri: skica za buduća istraživanja, Društvena istraživanja, 4-5(6-7), Zagreb, 587-605.

Šetić, Nevio, 2005. O povezanosti Istre s ostalim hrvatskim zemljama: Naša sloga 1870.1915., 2. izd., Zagreb: Dom i svijet.

Šetić, Nevio, 2005.(b) Razmatranje tijekova hrvatske nacionalne integracije u Istri, Časopis za suvremenu povijest, 3.

Šetić, Nevio, 2015. Istra u 19. stoljeću, u: Trogrlić, Šetić, 2015.

Šetić, Nevio, 2017. Ostvarenje suvremene hrvatske države: od pojave višestranačja 1989. do nastanka samostalne, međunarodno priznate $i$ teritorijalno cjelovite Republike Hrvatske, 2. izd, Zagreb: Družba „Braća Hrvatskoga Zmaja“.

Šišić, Ferdo, 2004. Povijest Hrvata: pregled povijesti hrvatskoga naroda, I-II, Split: Marjan tisak.

Taylor, Alan J.P. 1968. Borba za prevlast u Evropi 1848-1918., Sarajevo: V. Masleša.

Taylor, Alan J.P. 1990. Habsburška Monarhija 1809-1918., Zagreb: Znanje.

Toševa-Karpowicz, Ljubinka, 2007. D'Annunzio u Rijeci: mitovi, politika i uloga masonerije, Rijeka: Izdavački centar Rijeka.

Trogrlić, Stipan, 1993. Istra između klerikalizma i liberalizma: (kraj 19. i početak 20. stoljeća), Društvena istraživanja, 4-5(6-7), Zagreb, 657-673.

Trogrlić, Marko, Šetić Nevio 2015. Dalmacija i Istra u 19. stoljeću, Zagreb: Leykam international.

Tumpić, Dušan, 1993. Hrvatska Istra, Zagreb: Alinea.

Vivante, Angelo, 2002. Jadranski iredentizam, Zagreb: Dom i svijet. 


\section{Summary}

\section{The Causes of Conflict in Istria During the Formation of the Modern Croatian Nation in the Long $19^{\text {th }}$ Century}

Especially from the mid-19th century until mid-20th century, Istria was area of the national conflicts and untolerance between Italians, Croatians, and Slovenians, due to impact of the according national-international processes. Although there were also attempts of the life in harmony and tolerance, dramatic ungoings took place precisely during the struggle of the three nations in Istria for the right of national identity and self-determination. The denying of these rights of national sovereignity in this region was especialy problematic and implicated the conflicts. Beside this crucial inner factor the important role in the inducing of conflicts between three autochtonous nations in Istria and islands of Kvarner in the 19th century, have had some external elements clousely tied with changing dynamics of the international politics. The national unification of Italy and founding of the modern Italian state, the Kingdom of Italy 1861., is the external factor of the politics reality in this area. On the other side the defeath of Austria in the war against Prussia (1866.) and the following change of gravity of its politics, the accession of Italy to the Triple Alliance (1882.), the defeath of the italian collonial army by Adua (1896.), with following turn of its politics towards the Adriatic and Habsburg theritoryes, are the crucial external factors which affected politics of Italy and Habsburg Monarchy, and also on the development of the social, political and national processes in Istria.

This paper discusses also the importance of the overall structural elements, like european balance of powers, and also crucial regional equilibrium between Italy and Austria, which indirectly dettermined the faith Croatians, Slovenians, and Italians in the long 19th century. With the analyses of these internal and external elements important for Istrian historic reality, the paper shows the more complete picture of the causes of conflicts in Istria during the second half of the long 19th century, and also the situation in the moment of the beginning Great War in the year 1914.

Keywords: Croatian national integration in Istria; Croatians; Slovenians; Italians; the Kingdom of Italy; Austro-Hungarian Monarchy. 